\title{
Article \\ Challenges for the Integrated Management of Priority Areas for Conservation in Tamaulipas, México
}

\author{
Frida Carmina Caballero-Rico ${ }^{1}$ (D), Ramón Ventura Roque-Hernández ${ }^{2}$ (D), Ricardo de la Garza Cano ${ }^{1}$ (D) \\ and Eduardo Arvizu-Sánchez ${ }^{3, *}$ \\ 1 Center of Excellence, Autonomous University of Tamaulipas, Victoria City 87149, Mexico; \\ fcaballer@uat.edu.mx (F.C.C.-R.); rigarza@uat.edu.mx (R.d.l.G.C.) \\ 2 Faculty of Commerce, Administration and Social Sciences, Autonomous University of Tamaulipas, \\ Nuevo Laredo 88275, Mexico; rvhernandez@uat.edu.mx \\ 3 Faculty of Architecture, Design and Urbanism, Autonomous University of Tamaulipas, \\ Tampico 89337, Mexico \\ * Correspondence: earvizus@docentes.uat.edu.mx
}

check for updates

Citation: Caballero-Rico, F.C.;

Roque-Hernández, R.V.; de la Garza Cano, R.; Arvizu-Sánchez, E. Challenges for the Integrated Management of Priority Areas for Conservation in Tamaulipas, México. Sustainability 2022, 14, 494.

https://doi.org/10.3390/su14010494

Academic Editor: Just

Tomàs Bayle-Sempere

Received: 16 November 2021

Accepted: 15 December 2021

Published: 4 January 2022

Publisher's Note: MDPI stays neutral with regard to jurisdictional claims in published maps and institutional affiliations.

Copyright: () 2022 by the authors Licensee MDPI, Basel, Switzerland. This article is an open access article distributed under the terms and conditions of the Creative Commons Attribution (CC BY) license (https:// creativecommons.org/licenses/by/ $4.0 /)$.

\begin{abstract}
Protected areas (PAs) are considered as a globally accepted strategy for biodiversity conservation that demonstrates the difficulties in meeting the proposed objectives; therefore, different conservation schemes are promoted to integrate the design of interfaces that favor the exchange of knowledge among different sectors, systems and stakeholders. The objective of this study was to characterize challenges regarding the protection of natural protected areas and other biodiversity conservation schemes in Tamaulipas, Mexico. This paper analyzed 39 areas with some form of protection status in addition to the 70 national and international designations that are part of them. A document review and 13 semi-structured interviews were conducted with experts from the public, private, academic, and civil society sectors. The data were analyzed from a qualitative perspective using ATLAS.ti 9 software. The results show the overlapping of protection schemes in priority areas; the lack of policies and mechanisms that integrate the different schemes to facilitate the exchange between stakeholders; and regulatory, structural, governance, management, participation, and operational gaps, as well as the absence of comprehensive and long-term work. The importance of and challenges in articulating the different schemes and visions to achieve effective biodiversity conservation are evident.
\end{abstract}

Keywords: protected areas; other effective area-based conservation measures; conservation; management; integration

\section{Introduction}

Biodiversity management is a complex system involving stakeholders and institutions at different levels, where visions, interests, policies, strategies, rules and decision-making overlap, involving international, national, and local agencies [1,2] in a context where human behavior is the main driver of change [3].

Within this framework, protected areas (PAs) are an important strategy in the protection of biodiversity, particularly the services they provide to society and the environment when properly managed, as they can generate benefits beyond their boundaries [4-7]. However, despite the recognition of the benefits that these areas provide for climate change, people, water, food, natural disaster mitigation, tourism, cultural values, and the fulfillment of the millennium goals, they do not receive the required attention or funding $[8,9]$.

Borrini-Feyerabend, G. and Hill, R. (2019) p. 196, [10] highlight that "most of the world's protected areas and their respective systems are governed by the state, which involves complex systems of entities, agencies, administrative levels and stakeholders working with each other in collaboration, and sometimes in tension", resulting in inconsistent management throughout this network of protected areas. Experts have referred to 
"fragmented" and disorganized management, which is unable to prevent environmental degradation by focusing on economic gains, compromising the ability of protected areas to conserve biodiversity and ecosystems [11-14].

It has been found that PAs located in developing countries face various situations that interfere with their work and the achievement of their objectives. They are immersed in a limited physical and administrative infrastructure or in a complex hierarchy of inconsistent regulatory standards issued by different levels of government that obstruct both communication and information exchange $[10,15,16]$.

The COVID-19 pandemic and climate change highlight the convenience of the integrated management of the environment, land, and coordination of all sectors [17]. In this sense, several proposals posit that achieving biodiversity conservation requires the management of entire landscapes, and natural protected areas, although considered the axis of conservation, are not sufficient on their own [18].

It is argued that "humanity will soon define a new era for nature, one that seeks to transform decades of disappointing responses to the global biodiversity crisis" [19] (p. 217). Area-based conservation efforts, which include protected areas, are expected to expand and diversify [19] (p. 217). In this context, concepts such as planning, governance, social cohesion and interfaces between different stakeholders and systems are reconsidered $[9,10,20]$.

The planning process for the management of protected areas has been modified, moving from fragmented plans, with issues that are not necessarily significant for conservation, to strategic and specific management plans, where the establishment of objectives and the elaboration of management plans and decision-making processes are supported by the direct participation of the areas' administrators; the community; and stakeholders, who value, use or enjoy ecosystem services (ESs) supplied by an AP [2,21,22].

In recent decades, protected areas have been commonly found to be established and managed at the local level. It is proposed that with this proximity, local stakeholders, who are present in the territory, can participate more directly and generate innovative and flexible governance models that respond to their needs and contexts $[23,24]$. It is expected that government agencies will move from the establishment of public policies, or the direct administration of protected areas, to the development of their capacities to strengthen their work at the local level.

Achieving biodiversity restitution requires effective governance designed via the construction of productive and coherent interactions among people, sectors, and decisionmakers, based on shared values and objectives $[10,25,26]$. Understanding the relationships between human communities and their natural resources is based on the two-dimensional recognition of their relationship - a material, visible or tangible dimension and an immaterial, invisible, or intangible dimension-which provides structure and meaning to the processes $[27,28]$. The ecological and social coherence of governance units makes it possible to establish and comply with norms $[10,29,30]$.

In this context, efforts are being made to incorporate new elements into the process of biodiversity management, such as the work carried out by the Intergovernmental SciencePolicy Platform on Biodiversity and Ecosystem Services (IPBES), in which, by incorporating the voices of local communities or indigenous peoples, policies and actions that consider local contexts and diverse disciplines are designed [30].

Countries such as China have considered that the basic objective of protected areas is not only to preserve natural ecosystems and biodiversity, but also to ensure the economic development of the surrounding areas [31]. Although they have used various strategies, such as the establishment of an in-situ conservation system composed of nature reserves, national parks, scenic spots, forest parks, wetland parks and protected areas for aquatic germplasm, and have generated multiple policies to address ecological and biodiversity problems, it has not been possible to halt the deterioration of these areas [32].

The participative approach to planning and sourcing ES for PA management is considered important, as in the case of the Satchari National Park in Bangladesh, where it is 
recognized that sustainable land development, management and conservation within PAs can only be achieved with the strong participation of local communities [15].

The co-management governance system of Vatnajökull National Park, Iceland, is considered a model for more inclusive governance and a vehicle for the delivery of multiple ecosystem services. A study showed that it facilitates power sharing, which is transferred from the central to the local level; it is inclusive of stakeholders at multiple levels; it is well integrated and aligned with the overall institutional framework for land use. However, it also presents challenges associated with the complex stakeholder structure, narrowing of roles and attributions of key stakeholders [15,33].

In Mexico, according to the National Commission for the Knowledge and Use of Biodiversity (CONABIO), PAs are the most widely used strategy to conserve biodiversity, ecosystems, and the environmental services they provide to society [20].

Another scheme for biodiversity protection in Mexico is priority regions. From 1996 to 1999 , CONABIO coordinated exercises to identify priority terrestrial, hydrological and marine regions at the national level. Experts from different areas of conservation in Mexico $[34,35]$, and organizations such as the Mexican Conservation Fund, Pronatura, World Wildlife Fund (WWF) and The Nature Conservancy (TNC) participated in this process.

The National Program for Natural Protected Areas in Mexico recognizes the importance of their articulation with other conservation modalities-priority regions for conservation and regional sustainable development programs-articulations that become complex, where the spheres of competence are sometimes modified [36] (p. 418). The articulation of all conservation modalities is relevant for the fulfillment of the objectives by the year 2030, in which it has been proposed that at least $30 \%$ of terrestrial, freshwater, and marine ecosystems should be protected in order to halt further biodiversity loss [7].

In the case of Mexico, policies, strategies, and achievements in the management of priority areas for biodiversity conservation are issued by different levels of government depending on the type of conservation scheme. In this sense, their geographic location does not determine the level of administrative dependence, which can be national, state, or municipal, which results in fragmented visions of a territory, making conservation difficult.

At the national level, there is no similar study that comprehensively analyzes the different protection schemes for priority areas for conservation at the subnational level. Therefore, the contribution of this study is relevant, as, for the first time, it characterizes the confluence, interactions, overlaps and complementarities of the different schemes used and analyzed in a complete territory, such as the state of Tamaulipas, Mexico. It is considered relevant to evidence and argue the importance of integral conservation work at the local level with a long-term horizon beyond governmental levels.

The objective of this study was to characterize the challenges of the protection of natural protected areas and other biodiversity conservation schemes in Tamaulipas, Mexico.

The question posed in this study is as follows:

What are the challenges of integrated management for effective biodiversity conservation in Tamaulipas?

The paper is organized as follows: in the next section, a description of the materials and methods is provided; this is followed by the results; a discussion; and finally, conclusions, recommendations, and future work.

\section{Materials and Methods}

This study analyzed the challenges of effective biodiversity conservation in the state of Tamaulipas, Mexico. This research was conducted based on two different types of units: documents and interviews.

The first level of analysis was the documentary information gathered by different entities involved in the declaration or designation of the areas. Documents were available in archives, publications, and national or international databases. They contained variations depending on the conservation scheme, which makes it difficult to compare the data, terminology, criteria, and the years in which they were generated (1986 to 2019). It is, 
therefore obsoleted but high-quality information, and is considered a basic starting point for future research.

The second level of analysis was the collection of primary data information through semi-structured interviews with experts who actively participated in different processes, such as the planning, co-ordination, identification, or proposal of sites for the designation of priority areas, as well as users and people living in those targeted areas. The experts interviewed came from different public, academic, private, and non-governmental sectors.

Thirteen people were selected and explicitly invited to participate; among those who agreed to participate, when the interviews were conducted, different points of view, perspectives and experiences were obtained and scrutinized, but they all had a common thread or a common factor; therefore, saturation was found, since the points of view were found to be similar as the interviews progressed.

The third level of analysis was to contrast and validate the information generated in the documentary review and that provided by the experts. This stage allowed the validation of both the documents reported by the different entities and the information provided by the experts interviewed, which increases the credibility of the study.

The participants who took part in the validation process included: two community members from the main NPAs, one from the federal and one from the state, and two people from the private sector. In addition, the analysis was conducted taking into consideration the representativeness in the study areas, priority regions, AICAS/IBAs and protected natural areas, with the objective of determining the views of the interviewees.

Data that appeared in isolation in one of the sectors (for example, aspirational attitude) and were not comparable with other factors mentioned were eliminated.

Data triangulation was possible as there was time and resources to include several sources and methods of data collection. The data were derived from different actors in the process, which allowed the triangulation of data to build valid and quality information. Figure 1.

The following sites in Tamaulipas, Mexico were included in this research: Río Bravo Internacional, Matorral Tamaulipeco del Bajo Río Bravo, Presa Marte R. Gómez, Río San Juan y Río Pesquería, Presa Falcón, Laguna La Escondida, Delta del Río Bravo, Laguna Madre y Delta el Rio bravo/Laguna Madre, Desembocadura del río Soto la Marina, Encinares Tropicales de Loma Las Pitas y Sierra Maratines, Playa Rancho Nuevo/Playa Tortuguera Rancho Nuevo/ La Pesca Rancho Nuevo, Giro Tamaulipeco, Rancho Los Colorados y área de influencia, Laguna de San Andrés, Cerro del Metate, Río Tamesí, Pueblo ViejoTamiahua, Laguna de la Vega Escondida, Humedales del Sur de Tamaulipas y Norte Veracruz (Humedales de Altamira) ${ }^{*}$, Bernal de Horcasitas, Cenotes de Aldama, Reserva Bio Ventura, Sierra de Tamaulipas, Parras de la Fuente, Presa Vicente Guerrero, Parque Estatal El Refugio, Altas Cumbres, Ciudad Victoria Sierra Madre Oriental, Valle de Jaumave, Chihue Jaumave, Reserva de la biosfera El Cielo, Regalo de Dios, Rancho San Pedro, Sierra Tamalve, El Huizache, San Antonio Peña Nevada, Puerto Purificación, Sierra de San Carlos, Río San Fernando.

\subsection{Site Identification and Designations}

A search and the integration of information on priority areas for conservation were carried out in official federal newspapers and official state newspapers, regulatory documents, evaluation reports, government policy documents and reports from CONABIO, CONANP, Government of the State of Tamaulipas, IUCN, Birdlife International, Key Biodiversity Areas (KBAs), MAB-UNESCO, Ramsar and Protected Planet.

We worked with open dates; no limits or restrictions were established in the search for information. For PAs, we worked with the creation decrees and management programs from 1985 to 2019: Priority Terrestrial Regions, 2000; Priority Hydrological Regions, 2000 and 2007; Priority Marine Regions, 1998 and 2007 Important bird areas AICAS/IBAs, 1999 and 2000; an analysis of the CONABIO platform was performed, which cited its first documents in 1996 and publications in 1998. The work was performed with the 
international platforms where information on Key Biodiversity Areas KBAs can be found; information was found for 2000, 2008, 2015 and 2018 for Ramsar and MAB UNESCO from 1986 to date.

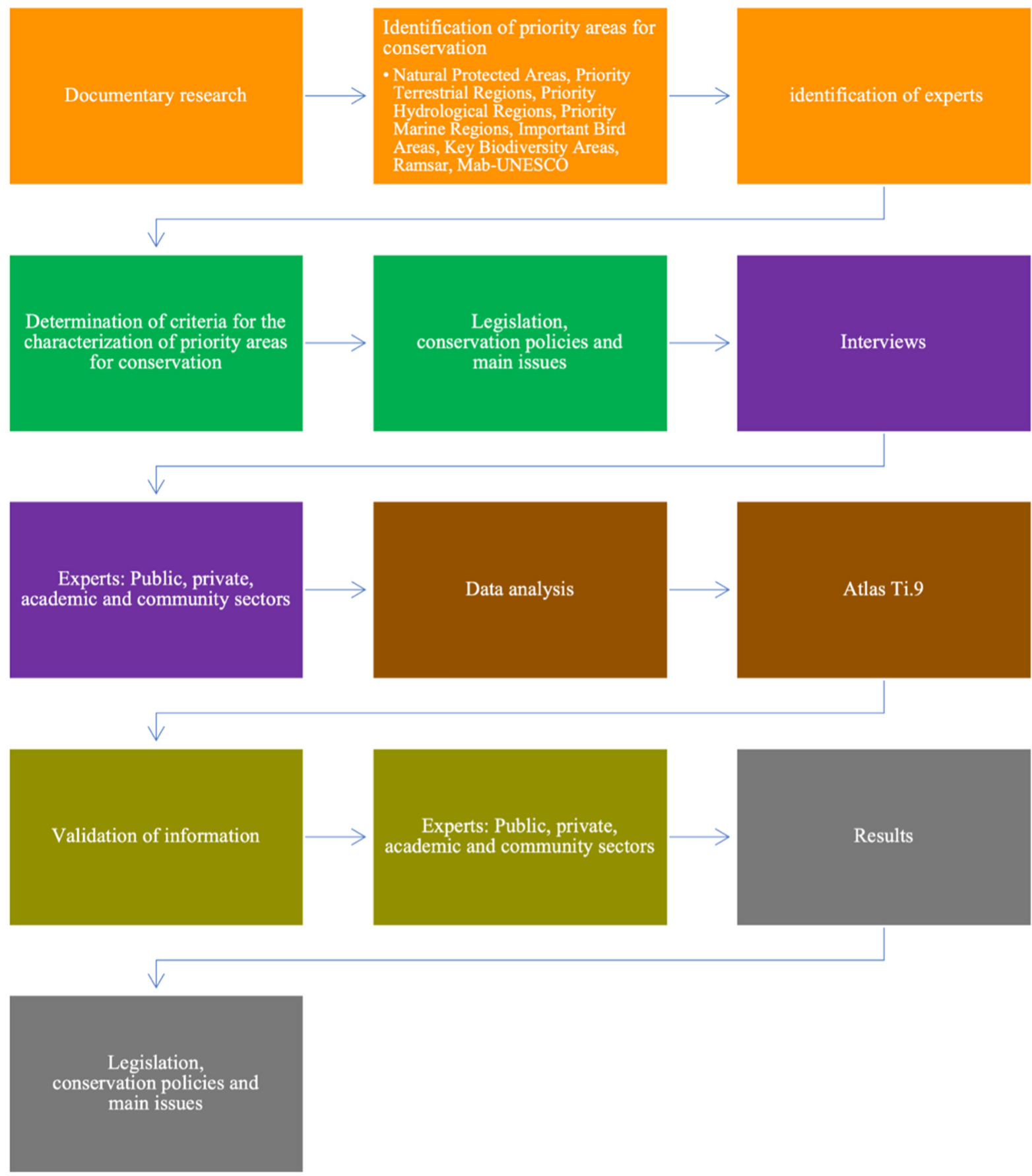

Figure 1. Workflow.

\subsection{Determination of Criteria for the Analysis of Each Site}

Digital files were created for each area analyzed, and the complete files for each protected area were studied. A review of each of the files of the sites considered to be priority sites for conservation, and which had a designation, was carried out following a checklist to ensure that the documents analyzed considered the same aspects; each of the characteristics was evaluated as present/absent, or with a certain level of compliance, and this was performed uniformly for all the documents or sources consulted (Table 1). It followed a 
traditional narrative approach by first identifying the key information, then synthesizing and analyzing the evidence on the specific issues for each of these characteristics.

Table 1. Criteria for the analysis of each site.

\begin{tabular}{|c|c|c|c|c|c|c|c|}
\hline NPA & PTR & PHR & PMR & IBA & KBA & Ramsar & $\begin{array}{c}\text { MAB- } \\
\text { UNESCO }\end{array}$ \\
\hline $\begin{array}{l}\text { Decree of } \\
\text { creation }\end{array}$ & Problems & Problems & Problems & IBA Criteria met & KBA status & \multirow{8}{*}{\multicolumn{2}{|c|}{$\begin{array}{l}\text { Associated with } \\
\text { two PAs }\end{array}$}} \\
\hline $\begin{array}{c}\text { Management } \\
\text { program }\end{array}$ & Conservation & Conservation & Conservation & Area & $\begin{array}{l}\text { Global KBA } \\
\text { criteria }\end{array}$ & & \\
\hline \multirow[t]{6}{*}{$\begin{array}{l}\text { Evaluation of } \\
\text { Management } \\
\text { Effectiveness }\end{array}$} & $\begin{array}{l}\text { Proportion of the } \\
\text { area under some } \\
\text { form of adequate } \\
\text { management }\end{array}$ & $\begin{array}{l}\text { Groups and } \\
\text { Institutions }\end{array}$ & $\begin{array}{l}\text { Groups and } \\
\text { Institutions }\end{array}$ & Protection status & $\begin{array}{c}\text { Year of } \\
\text { assessment }\end{array}$ & & \\
\hline & $\begin{array}{l}\text { Importance of } \\
\text { environmental } \\
\text { services }\end{array}$ & & & Key biodiversity & $\begin{array}{l}\text { National site } \\
\text { name }\end{array}$ & & \\
\hline & $\begin{array}{l}\text { Presence of } \\
\text { organized } \\
\text { groups }\end{array}$ & & & $\begin{array}{c}\text { Year of } \\
\text { compilation }\end{array}$ & System & & \\
\hline & $\begin{array}{l}\text { Conservation } \\
\text { policies }\end{array}$ & & & $\begin{array}{c}\text { Pressure/threats } \\
\text { to key } \\
\text { biodiversity }\end{array}$ & $\begin{array}{l}\text { Area of KBA } \\
\text { (ha) }\end{array}$ & & \\
\hline & Knowledge & & & IBA Protection & $\begin{array}{c}\text { Protected } \\
\text { area coverage } \\
(\%)\end{array}$ & & \\
\hline & Information & & & IBA Criteria & $\begin{array}{l}\text { Rationale for } \\
\text { qualifying as } \\
\text { KB }\end{array}$ & & \\
\hline
\end{tabular}

For the purpose of this publication, and in order to establish a framework for comparison, we selected and analyzed three variables with the greatest coincidence and, at the same time, made it possible to fulfill the objective of the study by answering the question posed and the comparison of the eight designations analyzed, namely, conservation regulations and policies, the status of priority areas for biodiversity conservation and problems of priority areas for conservation.

\subsection{Interviews with Experts}

The third part of the research was designed to gain the perspective of experts in order to gather opinions and visions about the challenges for the conservation of the areas considered important for biodiversity conservation in Tamaulipas. Thirteen semistructured interviews were conducted, and the questions that guided the interviews were as follows:

1. How were the priority areas designated?

- (Natural Protected Areas, Priority Terrestrial Regions, Priority Marine Regions, Priority Hydrological Regions, AICAS/IBAS in which you participated)

- Who convened the meeting? Who participated? What is the basis?

2. What has been the importance of priority areas?

- What impact have they had on conservation?

- Is conservation monitoring carried out? How is the performance of those responsible for these areas?

3. What challenges do the management and conservation of priority areas present? 
- What is the status of conservation schemes?

- What are the structures or systems of support?

- Do they have a structure, budget, and staff?

- Who would be the relevant actors in the process of developing the state system of priority areas for conservation?

According to the Helsinki protocol, in order to protect the anonymity of the interviewees, they were identified by the sector in which they participate rather than their institution, age or education level or gender [37]. The preservation of anonymity does not prevent an integrated and accurate presentation of the analysis.

CONABIO documents were reviewed, and the participants for the designations made between 1996 and 1998 for Tamaulipas were located there. For the natural protected areas, two experts who had administered them were contacted (Tables 2-4).

Table 2. Interviewees at different stages of the process.

\begin{tabular}{cccc}
\hline Stage & National Scope & State Scope & Total of Interviewees \\
\hline Planning and Coordination & 4 & 2 & 6 \\
\hline Identification for designation & 0 & 3 & 3 \\
\hline Community members & 0 & 2 & 2 \\
\hline Users & 0 & 2 & 2 \\
\hline Total of interviewees & 4 & 9 & 13 \\
\hline
\end{tabular}

Table 3. Interviewees by study areas.

\begin{tabular}{cccc}
\hline Level & $\begin{array}{c}\text { Priority Regions } \\
\text { AICAS/IBAs }\end{array}$ & $\begin{array}{c}\text { Protected } \\
\text { Natural Areas }\end{array}$ & Total of Interviewees \\
\hline National & 4 & & 4 \\
\hline State & 3 & 6 & 9 \\
\hline Total & 7 & 6 & 13 \\
\hline
\end{tabular}

Table 4. Distribution of interviews by affiliation.

\begin{tabular}{|c|c|c|c|c|c|c|c|c|c|c|c|c|c|c|}
\hline Sector & 1 & 2 & 3 & 4 & 5 & 6 & 7 & 8 & 9 & 10 & 11 & 12 & 13 & Total \\
\hline Public sector & $x$ & $x$ & $x$ & $x$ & & & & & & & & & & 4 \\
\hline Non-governmental sector & & & & & & & $x$ & $x$ & $x$ & & & & & 3 \\
\hline Academic sector & & & & & $x$ & $x$ & & & & & & & & 2 \\
\hline Private sector & & & & & & & & & & & & $x$ & $x$ & 2 \\
\hline Community members & & & & & & & & & & $x$ & $x$ & & & 2 \\
\hline
\end{tabular}

First level of selection (6 participants).

First, those responsible for planning and/or coordination were identified and asked to participate. At this level, all those invited agreed to participate. One person was interviewed for each designation, four at the national level, two at the state level, one with experience in the administration of state natural protected areas and one with experience in federal natural protected areas.

Second level of selection-Identification for designation (field work) (3 participants).

The files for each designation in Tamaulipas were reviewed; 4 researchers were contacted, and invitations were sent.

One did not answer until after the research was completed, and three accepted the interview.

Third level community members (2 participants). 
The selection criteria were that they were knowledgeable of the protected natural area and conservation.

One was a community guide of recognized national and international prestige in the Laguna Madre Federal PNA and the Río Bravo Delta.

The other was a social actor in El Cielo Biosphere Reserve.

Fourth user level private sector (2 participants).

Two people from the private sector were interviewed, one from the center and the other from the south of the state.

For the analysis of the KABs, information was collected through the internet; since this designation is made by integrating different sources, an interview on this designation was not carried out.

The interviewees belong to the following organizations: National Autonomous University of Mexico, National Commission for the Knowledge and Use of Biodiversity, Autonomous University of Tamaulipas, Civil Society of the Laguna Madre and Delta del Rio Bravo PAs and El Cielo Biosphere Reserve. The geographical location of the experts was Mexico City, Saltillo Coahuila, Ciudad Victoria Tamaulipas, Tuxtla Gutierrez Chiapas. The interviews were conducted by the same person through the https: / / www.microsoft.com/es-mx/microsoft-teams/log-in (accessed on 15 November 2021) platform and by telephone.

We consider the opinion of the interviewees to be fully representative as all of them have a deep knowledge of the priority areas for conservation and the different protection schemes. In addition, they have extensive experience in this field and have participated directly in the different stages-either in the planning, coordination, identification, or designation of priority areas to plan, coordinate or identify areas for designation - of the original work conducted in these areas in Tamaulipas, Mexico. They are known nationally and internationally in their field of expertise.

\subsection{Data Analysis}

The 13 interviews were comprehensively transcribed into a Word document and sent to the interviewees for validation. Some interviewees made clarifications, which were included in the qualitative model.

Each of the 13 completed documents were incorporated into the software https: / / atlasti.com/es / (accessed on 15 November 2021) version 9 software [38], and comprehensively analyzed, and initial coding was performed. Eighteen codes and 139 citations were identified; the number of citations was associated with each code and respondent.

A second review of the documents was carried out, and the codes assigned in the first coding were validated and/or modified.

From the second analysis of the interviews, 10 codes and 113 citations were defined, and the number of citations was associated with each code and interviewee.

In the software, the codes were associated with textual quotations in each document; then, combinations were made through subgroups or networks, diagrams, and graphs.

The results of the coding were sent again to the experts for validation, and the suggested modifications were made.

\section{Results}

\subsection{Documental Analysis}

A total of 39 important conservation sites classified into 8 types were identified: 13 protected areas, 13 terrestrial priority regions, 5 marine priority regions, 5 hydrological priority regions, 13 important bird areas (IBAs), 17 key biodiversity areas (KBAs), 2 Ramsar and 2 UNESCO-MABs (Figure 2). 


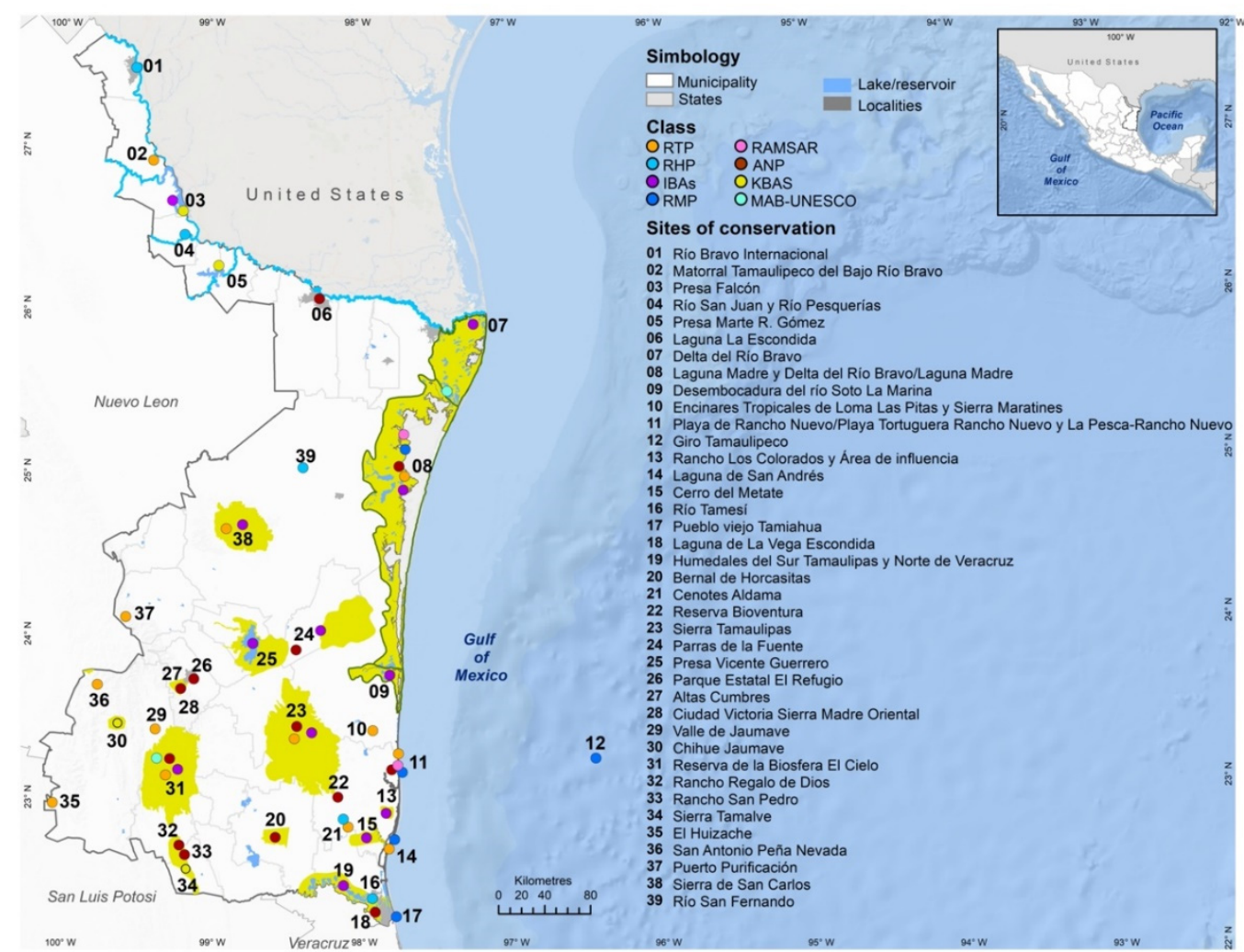

Figure 2. The 39 priority areas for conservation located in Tamaulipas are represented; the symbology represents the conservation schemes.

Conservation designations were found to overlap, with up to seven coinciding, as in the case of Laguna Madre. There are different levels of overlap between designations, the highest being KBAs (Figure 3).

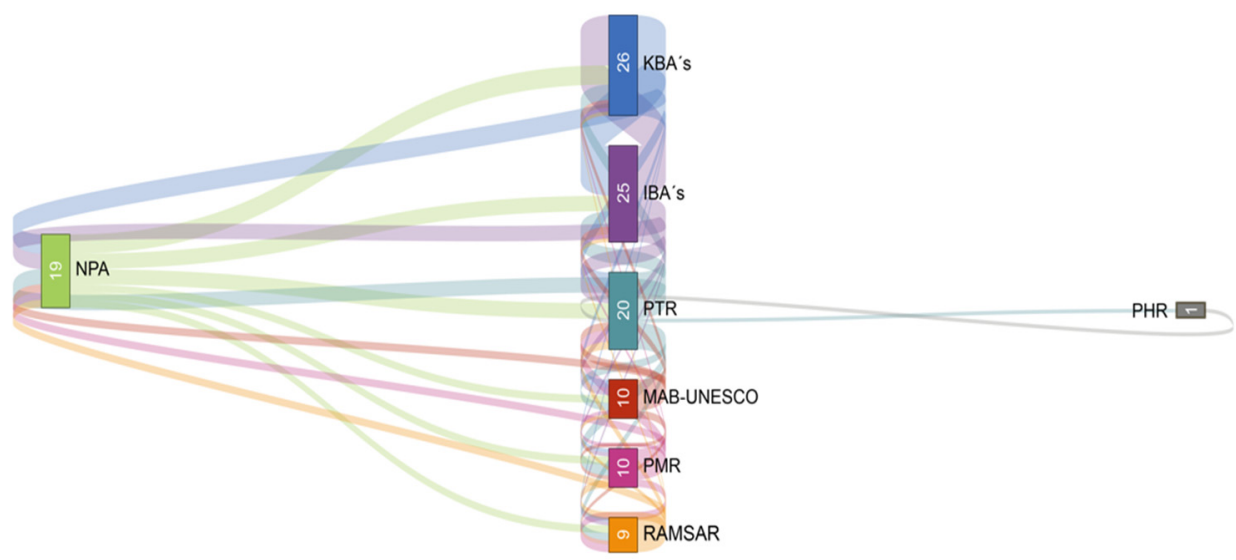

Figure 3. Overlapping conservation designations.

\subsection{Conservation Regulations and Policies}

\subsubsection{Natural Protected Areas in Tamaulipas}

There are 13 PAs in Tamaulipas with a creation decree or certificate [39-52]. The conservation policies to which they are subjected are described in the management programs of each PA [39,53-56]. The creation of PAs is based on the General Law on Ecological Equilibrium and Environment Protection, [39] which defines the legal procedures, classification, scope, administration and management and norms to which PNAs are subjected in ARTICLE 2o.- II.; CHAPTER I ARTICLE 44. SECTION II Art. 46, SECTION III. ARTICLE 57, 
ARTICLE 61, ARTICLE 65, ARTICLE 74 and 77 BIS. SECTION IV, ARTICLE 76. SECTION V ARTICLE 77 BIS.

\subsubsection{Priority Regions}

There are 24 priority regions in Tamaulipas, and they do not have a legal basis or conservation policies. There are 13 priority terrestrial regions, and they are the result of the work coordinated by CONABIO, "with the purpose of identifying in the continental part of the national territory, spaces with a comparatively greater ecosystem and specific richness than in the rest of the country, as well as a significant functional ecological integrity and where, in addition, there is a real opportunity for conservation". The World Wildlife Fund (WWF), the United States Agency for International Development (USAID), The Nature Conservancy (TNC) and the Fondo Mexicano para la Conservación de la Naturaleza (FMCN) participated in the project, and the Instituto Nacional de Ecología was the regulatory authority assigned by the federal government in this process. The results were obtained from 2 workshops held in 1996 and 1999 at Conabio's facilities, in which the contributions, knowledge and experiences of specialists, researchers, reviewers and Conabio personnel were integrated [34].

There are five priority marine regions located in Tamaulipas: CONABIO with the support of the David and Lucile Packard Foundation (PACKARD), the Agency for International Development of the Embassy of the United States of America (USAID), the Mexican Fund for the Conservation of Nature (FMCN) and the Mexican Fund for the Conservation of Nature (FMCN) and the World Wildlife Fund (WWF), which are brought together through multidisciplinary workshops, and a group of experts from academic, governmental, private, social and non-governmental conservation organizations [57].

Hydrological priorities, five of which are located in Tamaulipas, are the result of CONABIO's work in 1998, which aimed to identify the main sub-basins and aquatic systems of the country considering the characteristics of biodiversity and the social and economic patterns of the identified areas, in order to establish a frame of reference that can be considered by the different sectors for the development of research plans. Specialists from academia, government and non-governmental organizations participated in the study, with financial support from the Biodiversity Trust Fund, The David and Lucile Packard Foundation, The United States Agency for International Development, the Mexican Fund for Nature Conservation, and the World Wildlife Fund [58].

\subsection{Status of Priority Areas for Biodiversity Conservation}

\subsubsection{Natural Protected Areas}

Of the 13 existing NPAs in Tamaulipas, by origin, $46.15 \%$ are state, $23.08 \%$ are federal, $23.08 \%$ are Voluntary Dedicated Conservation Areas (ADVC) and $7.69 \%$ are municipal. The first NPA was established in 1985, and the last one in 2019. Four NPAs do not have a management program: two are federal-Rancho Nuevo Beach (1986) and Sierra de Tamaulipas (2016); one is state-Bernal de Horcasitas (1997); and one is municipal—Laguna de la Vega Escondida (2003).

A characterization of the 13 PAs in Tamaulipas is presented in Figure 4.

The evaluation of management effectiveness has been carried out in federal PAs; of these, the Laguna Madre and Delta del Rio Bravo were evaluated in 2018, obtaining a highly effective rating $[53,54]$ (Table 5). 


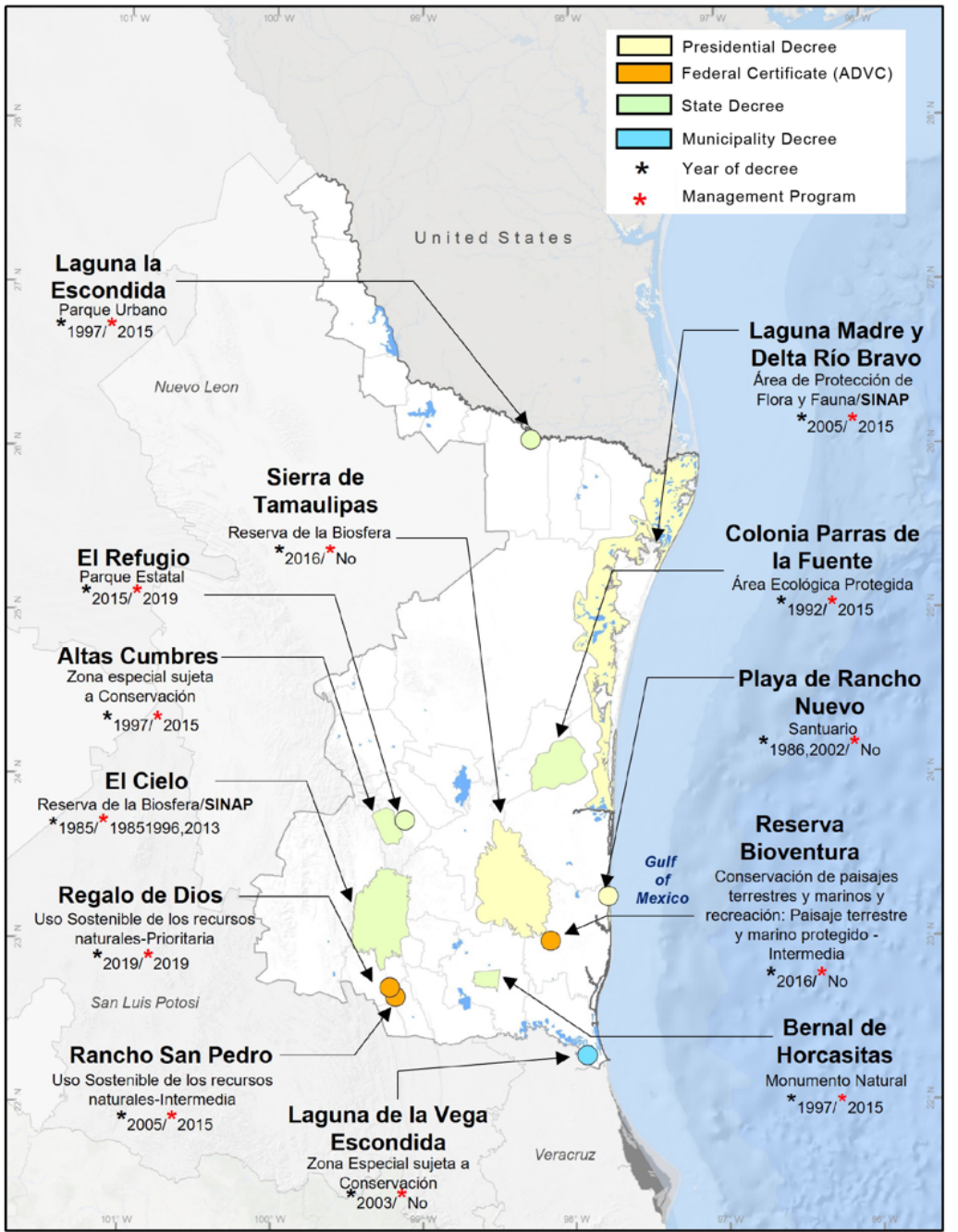

Figure 4. The 13 Natural Protected Areas in Tamaulipas, indicating the origin and year of the decree or certificate and whether they have a management program.

Table 5. Evaluation of the effectiveness of federal PAs.

\begin{tabular}{cccccccc}
\hline PA & $\begin{array}{c}\text { Effectiveness } \\
\text { Index }\end{array}$ & $\begin{array}{c}\text { Context and } \\
\text { Planning } \\
\text { Index }\end{array}$ & $\begin{array}{c}\text { Administrative } \\
\text { and Financial } \\
\text { Index }\end{array}$ & $\begin{array}{c}\text { Usages and } \\
\text { Benefit } \\
\text { Index }\end{array}$ & $\begin{array}{c}\text { Government } \\
\text { and Social } \\
\text { Practice Index }\end{array}$ & $\begin{array}{c}\text { Handling } \\
\text { Service }\end{array}$ & Total Score \\
\hline APFF & & & & & & & \\
Laguna & 61 & 59 & 55 & 67 & 74 & 57 & 74 \\
Madre and \\
$\begin{array}{c}\text { Delta del } \\
\text { Río }\end{array}$ & $\begin{array}{c}\text { Highly } \\
\text { effective }\end{array}$ & $\begin{array}{c}\text { Partially } \\
\text { effective }\end{array}$ & $\begin{array}{c}\text { Partially } \\
\text { effective }\end{array}$ & $\begin{array}{c}\text { Highly } \\
\text { effective }\end{array}$ & $\begin{array}{c}\text { Highly } \\
\text { effective }\end{array}$ & $\begin{array}{c}\text { Partially } \\
\text { effective }\end{array}$ & $\begin{array}{c}\text { Highly } \\
\text { effective }\end{array}$ \\
Bravo & & & & & & \\
\hline
\end{tabular}

The evaluation system is made up of 5 components and 48 indicators. Each of the indicators has a numerical rating from 0 to 3 , and algorithms were designed to calculate the effectiveness index and sub-indexes for each of the five components. In the following tables of the components and their indicators, the indicators of the Enhancing our Heritage Toolkit: Assessing Management Effectiveness of Natural World Heritage sites, the IUCN Global Standard Green List and the NSW State Parks System, Australia, are shown in gray. The remaining indicators correspond to the Management Effectiveness Tracking Tool (METT). Its valuation at the international level is PAs with the partially effective management index [53,54]. 


\subsubsection{Priority Terrestrial Regions (PTRs)}

There are 13 PTRs in Tamaulipas, covering 18,981 hectares, which constitutes $24.70 \%$ of the state [34]. All of the information was reviewed and analyzed from the data sheets prepared by the specialists for the identification of each PTR. The results of section $\mathrm{H}$ related to conservation and comprising five variables are presented (Figure 5).

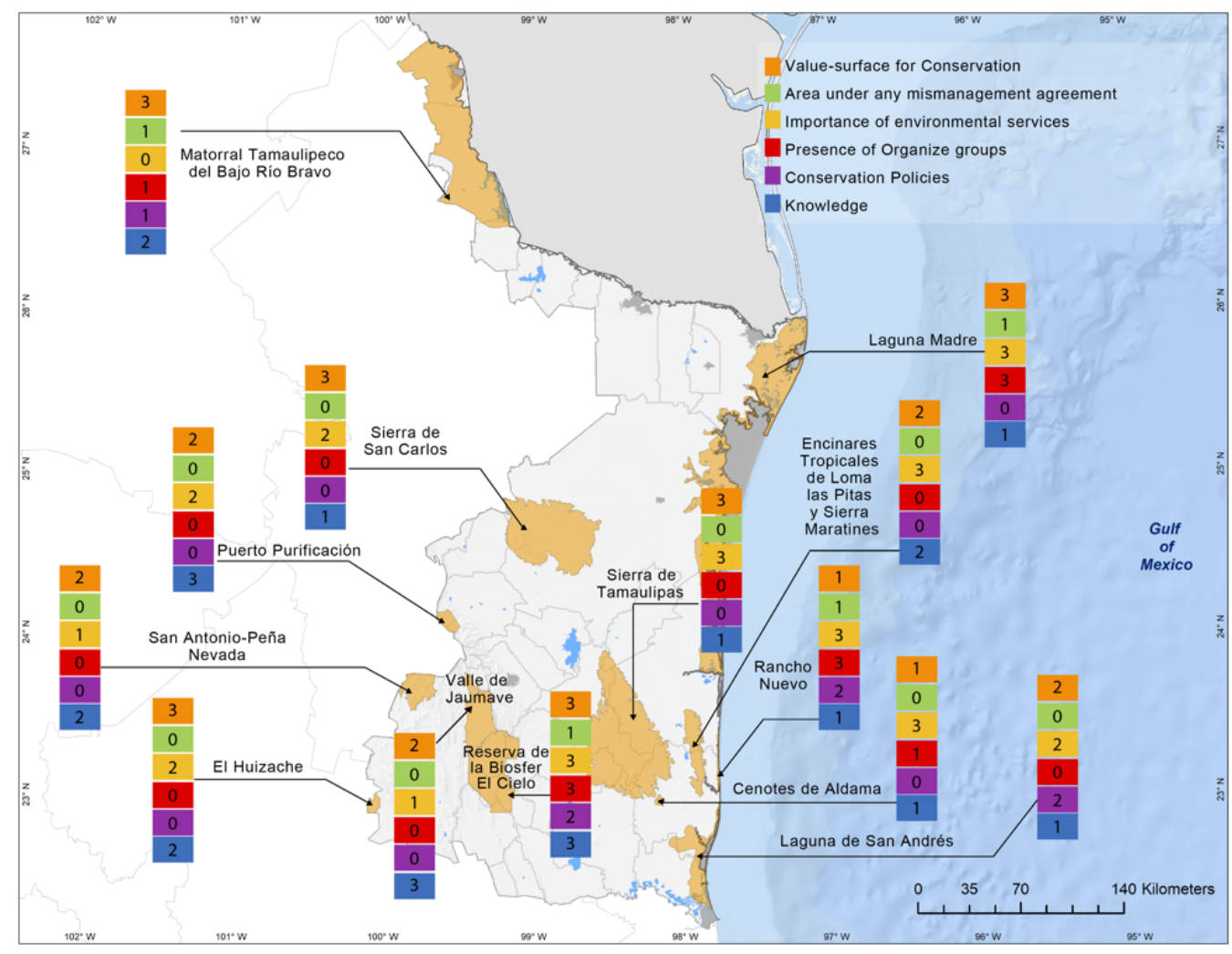

Figure 5. Priority terrestrial regions of Tamaulipas.

- The knowledge and conservation policy status are reported with a brief description; therefore, following the same criteria as the variables already rated in the card, they were converted into numbers of conservation policies: 3 (integrated actions), 2 (some actions), 1 (incipient or some interest) and 0 (non-existent). Knowledge: 3 (well known), 2 (known), 1 (little known) and 0 (not known).

- Information, including the citation where the information was obtained, the name of the specialists who participated in the information gathering and, in some cases, the institutions where the information was obtained. It was found that 42 national and international experts, students and thesis students participated in the survey, including Dr. L. Arriaga, Dr. E. Enkerlin and F. González-Medrano, assigned at that time to CONABIO, Pronatura and the Institute of Ecology of the National Autonomous University of Mexico (UNAM), respectively.

\subsubsection{Priority Marine Regions (PMRs)}

The characteristics of the five PMRs located in Tamaulipas were determined by a group of 74 experts from the academic, governmental, private, social, and non-governmental conservation organizations convened by CONABIO in 1998. These experts assigned values to the PMRs based on environmental, economic and threat criteria. The classification of the PMRs comprises four variables: areas of high biodiversity $(\mathrm{AB})$, areas that present some threat to biodiversity (AA), areas of use by sectors (AU) and areas lacking biodiversity information (AFI). The specialists noted that the most important criterion is that of high biodiversity. This exercise involved approximately 300 participants; in the cards for each 
region, the institutions of affiliation of the participants appear, namely, UNAM, Universidad Autónoma Metropolitana (UAM), Instituto Politécnico Nacional (IPN), Universidad Autónoma de Tamaulipas (UAT), Universidad del Noreste (UNE) and Secretaría de Marina (SM) $[58,59]$. The PMRs do not have a legal basis or decree of creation (Figure 6).

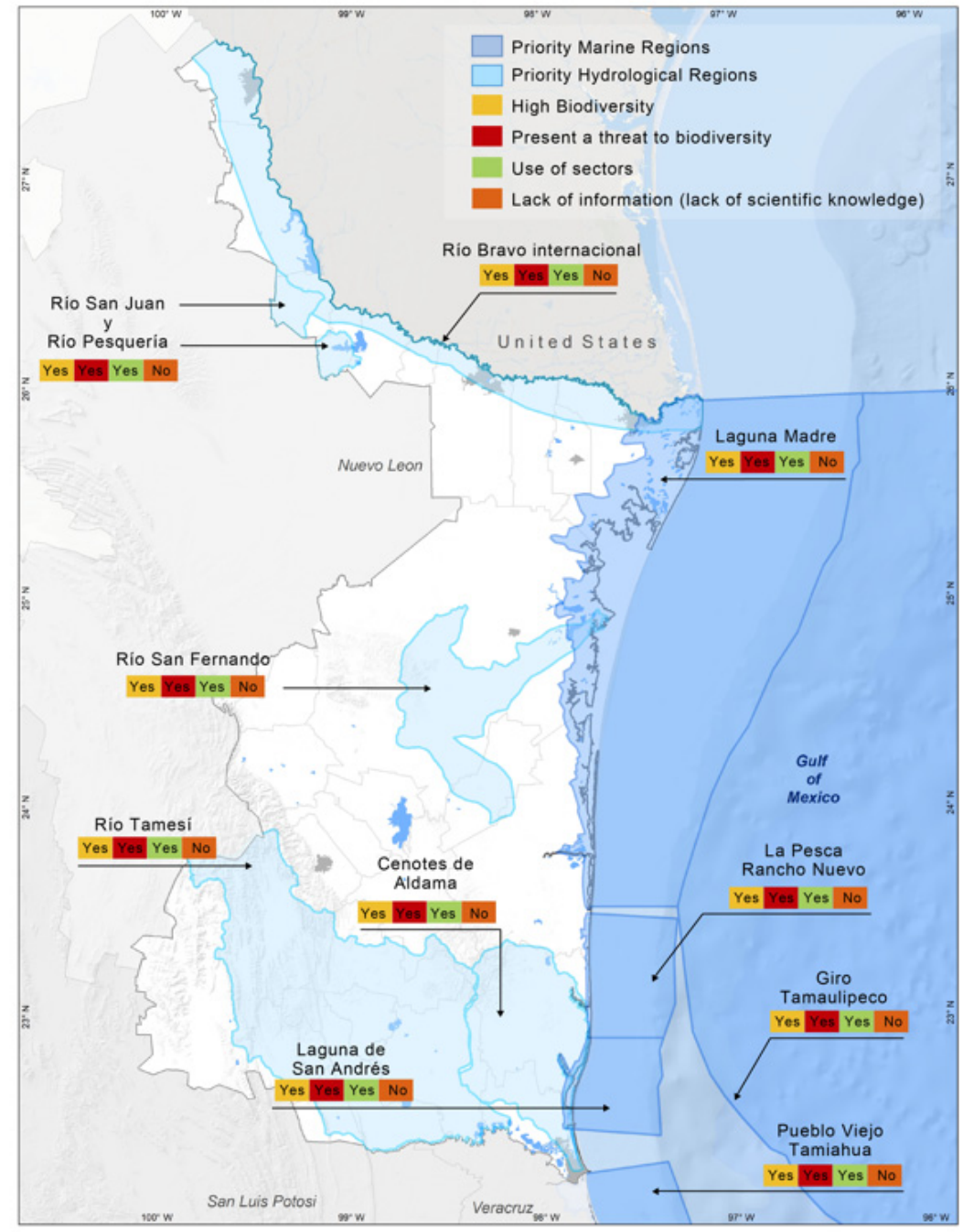

Figure 6. Priority hydrologic regions.

\subsubsection{Priority Hydrologic Regions (PHRs)}

Five PHRs were identified in Tamaulipas [58,59]. The technical records prepared by the specialists convened by CONABIO to evaluate each PHR considered the status of 4 variables, as presented in Figure 4: regions of high biodiversity (AAB), present threat to biodiversity (AA), regions of use of sectors (AU) and lack of biodiversity information (AD) (Figure 6).

The identification work included specialists from El Colegio de la Frontera Norte (COLEF); Universidad Autónoma de Nuevo León (UANL); Instituto Tecnológico y de Estudios Superiores de Monterrey (ITESM); Instituto de Ecología y Alimentos (IEA), UAT; Bioconservación A.C.; Instituto de Ciencias del Mar y Limnología, UNAM; Instituto Tecnológico de Cd. Victoria (ITCV); Universidad del Noreste (UNE); Comisión Nacional del Agua (CONAGUA); and Secretaría de Medio Ambiente, Recursos Naturales y Pesca (SEMARNAP), nowadays Secretaría del Medio Ambiente y Recursos Naturales (SEMARNAT) $[58,59]$. 


\subsubsection{Important Bird Areas (IBAs)}

Since the 1970s, the BirdLife Partnership has worked collaboratively with various nongovernmental organizations to identify, document, and protect the world's most important sites for bird conservation, IBAs for Important Bird Areas, known in Mexico as AICAS. All existing IBAs qualify as KBAs, either as Global KBAs, if they meet the criteria of the Global Standard, or as Regional KBAs, and do not have a legal basis or decree of creation. In Tamaulipas, 13 sites proposed and compiled by experts and students from Mexico and 1 from the USA were identified. All of the sites were selected because, at the time, there was a species on the IUCN Red List [35,55] (Figure 7).

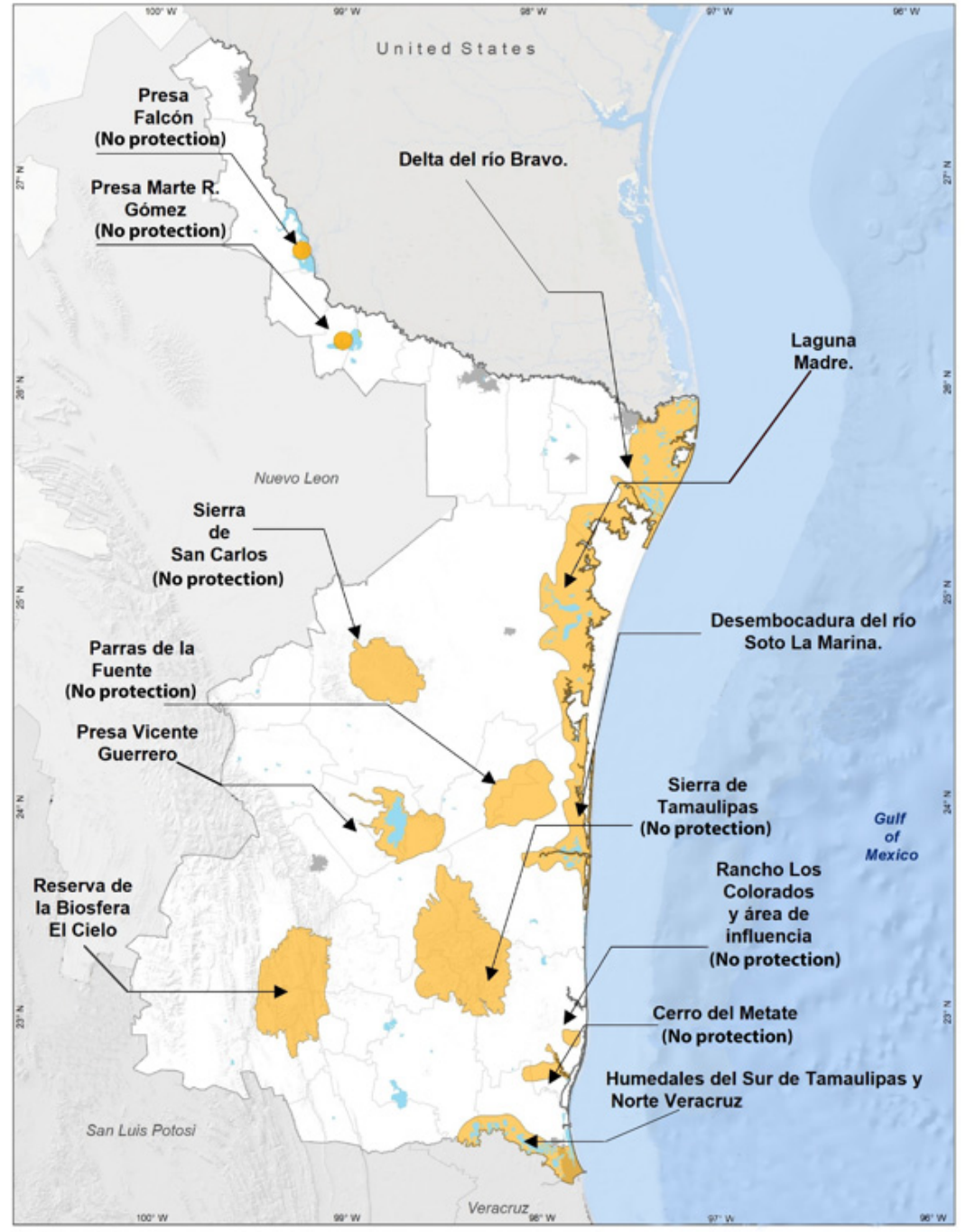

Figure 7. Important bird areas.

\subsubsection{Key Biodiversity Areas (KBAs)}

The World Database on Key Biodiversity Areas reports that 17 KBAs are located in Tamaulipas (Figure 8). To be considered a KBA, sites must meet one or more of 11 criteria in the 5 categories (threatened biodiversity, geographically limited biodiversity, ecological integrity, biological processes, and irreplaceability). Information on the qualification of KBAs was compiled from different sources, such as Important Bird and Biodiversity Areas (IBA), identified by BirdLife International; Alliance for Zero Extinction (AZE) areas containing the remaining population of one or more Critically Endangered or Endangered species; and KBAs in relation to a range of vertebrate, invertebrate and plant taxa identified through ecosystem profiles compatible with the Essential Ecosystem Partnership Fund. 


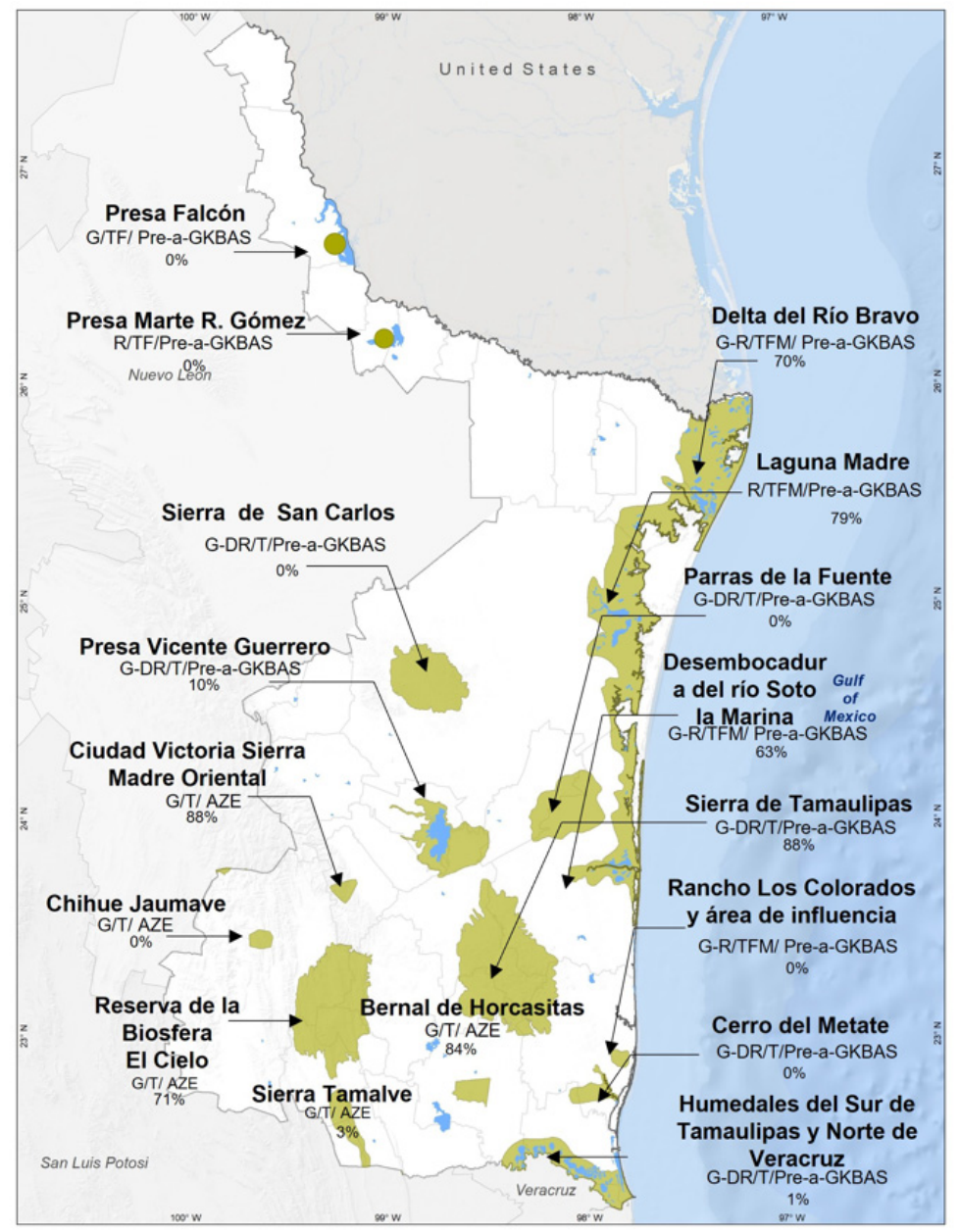

Figure 8. Key biodiversity areas. $\mathrm{G}=$ global; $\mathrm{R}=$ regional; $\mathrm{G} / \mathrm{RD}=$ global $/$ regional to be determined . $\mathrm{T}=$ terrestrial; $\mathrm{TF}=$ terrestrial, freshwater; $\mathrm{TFM}=$ terrestrial, freshwater, marine pre-a GKBAS = priority for re-assessment against the Global KBA Standard. AZE = Alliance for Zero Extinction (2018).

KBAs are identified by the KBA Partnership, composed of BirdLife International, IUCN, the Amphibian Survival Alliance, Conservation International, the Essential Ecosystem Partnership Fund, the Global Environment Facility, Global Wildlife Conservation, NaturServe, Royal Society for the Protection of Birds, Wildlife Conservation Society, and the World Wildlife Fund $[56,57]$. There are different levels of protection depending on the percentage of protected KBAs, namely, fully covered by protected areas (at least $98 \%$ of the KBA area), partially covered (between $2 \%$ and $98 \%$ and no protected area coverage in each country) and the average percentage of KBAs covered by protected areas in each country $[56,57]$.

\subsubsection{International Designations}

MAB-UNESCO designations are considered as "learning sites for sustainable development" (60), which, through the interaction between social and ecological systems, raise awareness of local problems. Biosphere reserves are proposed by each country and designated within the framework of the intergovernmental MAB Program by the DirectorGeneral of UNESCO, following the decisions of the MAB International Coordinating Council (MAB ICC). Their status is internationally recognized, and they remain under national jurisdiction [60].

The inclusion of a wetland on the Ramsar list represents the government's commitment to taking the necessary measures to ensure that its ecological character is maintained. These Ramsar sites acquire a new status at the national and international level. They 
are recognized as being of great value, not only for the country or countries in which they are located, but for humanity as a whole [61]. In Tamaulipas, the four international designations are associated with the three protected areas (Table 6).

Table 6. International designations in priority areas for conservation.

\begin{tabular}{|c|c|c|c|c|c|c|c|c|}
\hline $\begin{array}{c}\text { Management } \\
\text { Category }\end{array}$ & Name & Decree & Extension & $\begin{array}{c}\text { MAB- } \\
\text { UNESCO }\end{array}$ & $\begin{array}{c}\text { MAB- } \\
\text { UNESCO } \\
\text { Evaluation }\end{array}$ & Ramsar & $\begin{array}{c}\text { Ramsar } \\
\text { Evaluation }\end{array}$ & $\begin{array}{c}\text { Ramsar } \\
\text { Last Published } \\
\text { Date }\end{array}$ \\
\hline $\begin{array}{l}\text { Reserva de la } \\
\text { Biosfera }\end{array}$ & El Cielo & State & $\begin{array}{c}144 \\
53051-00\end{array}$ & 1986 & 2002,2013 & & & \\
\hline Santuario & $\begin{array}{c}\text { Playa } \\
\text { Tortuguera } \\
\text { Rancho } \\
\text { Nuevo }\end{array}$ & Federal & 90.65 & & & 2003 & $\mathrm{~N} / \mathrm{A}$ & $\begin{array}{l}27 \text { November } \\
2003\end{array}$ \\
\hline $\begin{array}{l}\text { Área de } \\
\text { Protección de } \\
\text { Flora y Fauna }\end{array}$ & $\begin{array}{c}\text { Laguna } \\
\text { Madre y } \\
\text { Delta Río } \\
\text { Bravo }\end{array}$ & Federal & 572808.6 & 2006 & $\begin{array}{c}\text { No } \\
\text { evaluation }\end{array}$ & 2004 & $\mathrm{~N} / \mathrm{A}$ & 2 February 2004 \\
\hline
\end{tabular}

\subsection{Problems of Priority Areas for Conservation in Tamaulipas}

The problems were identified based on the management plan documents for the natural areas, priority region files, IBAs and KBAs (Figure 9). Each of the priority regions in Tamaulipas faces specific problems, but in general, they all face the modification of the environment due to the development of uncontrolled urban settlements, urbanization, agricultural activities and the alteration of vegetation, which translates into the loss of the original surface area and the high fragmentation of habitats; high levels of industrial, urban, agrochemical, solid waste and wastewater pollution; overexploitation of aquifers, which prevents their replenishment, the formation of canals and drying up; the unsustainable use of fauna: introduced species, illegal fishing, violation of closed seasons and minimum sizes and non-selective traps; inadequate management practices of agricultural and livestock fields, logging and hunting [34,35,58,59,62,63].

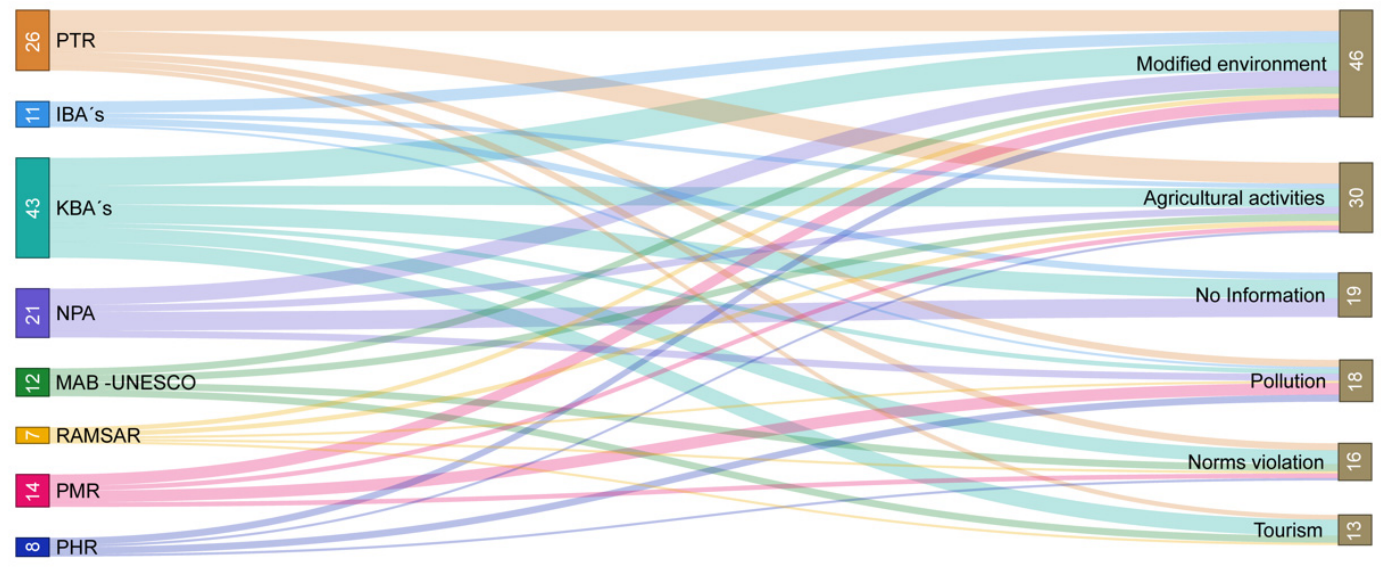

Figure 9. Problems of priority areas for conservation in Tamaulipas.

\subsection{Interviews with Experts}

From the analysis of the interviews, 10 codes and 113 quotes were identified (Figure 9). The boxes represent the sectors to which the 13 interviewees belong, each of the 10 codes generated from the interviews are represented in color and the lines show the number of quotes associated with each code and interviewee. The information obtained from the responses obtained from 10 interviewees was sent; this consisted basically of the wording 
of the quotes, not the derived codes. Adjustments were made, which did not require recoding, they were resent to the interviewees and there were no more modifications from that point onward.

The nomenclature used for identification was as follows: SPF = public sector; SA = academic sector; $\mathrm{SONG}=$ non-governmental organizations; $\mathrm{SP}=$ private sector and $\mathrm{SC}=$ community member (Figure 10).

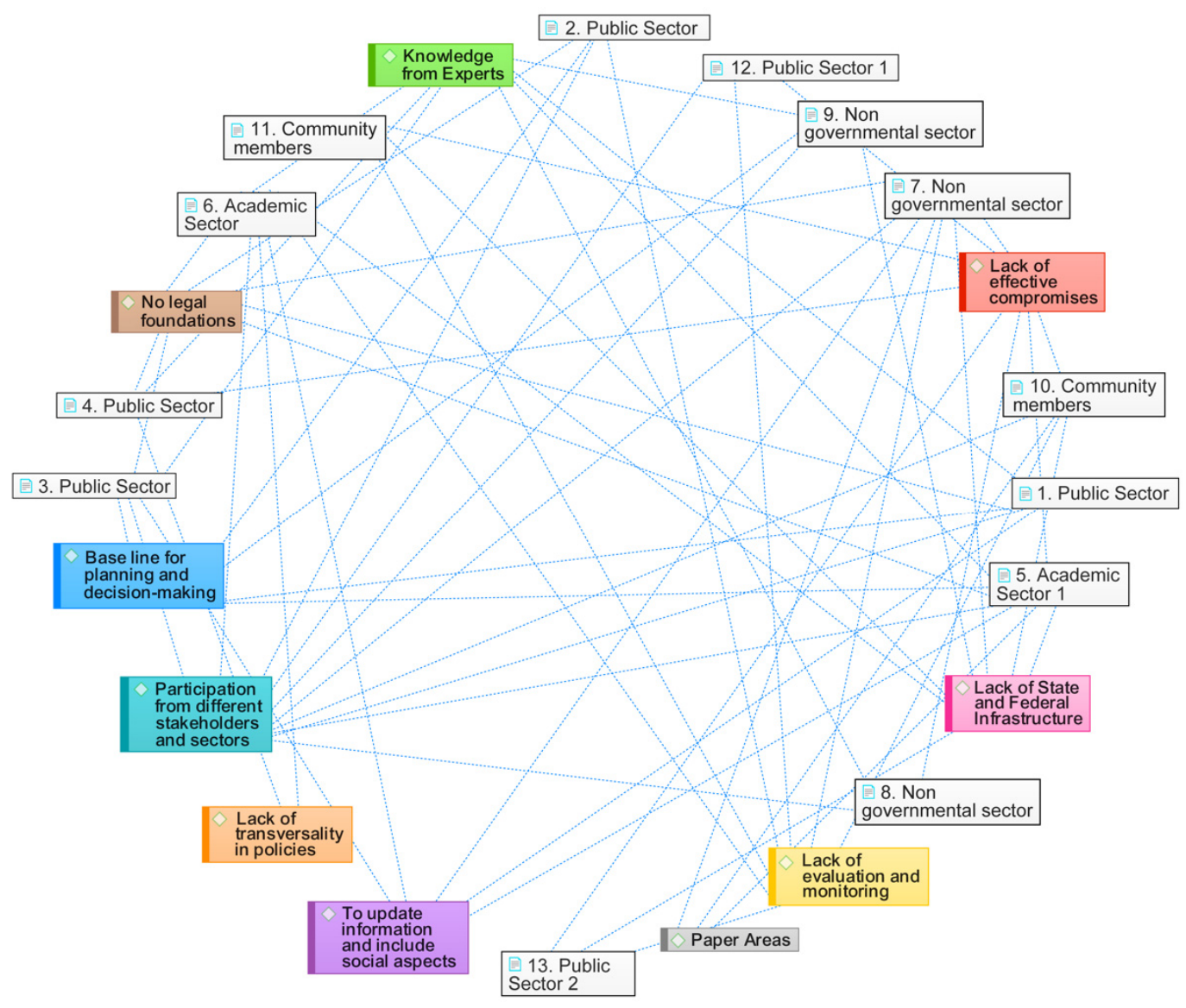

Figure 10. Codes and distribution by participants.

In the following, we show the interviewees' responses to the three open-ended questions that were asked.

\subsubsection{Question 1. How Were the Priority Areas Identified?}

Below are some fragments of the answers of the experts interviewed.

SPF1: "One decision we made was that the definition of the areas should be based on the experience and knowledge of each participant, by defining an area that they knew, would keep it."

SA1: "We invited researchers who had knowledge of the sites in Tamaulipas, I incorporated the sites where there were species also describing what factors from could be considered indicators or main risk factors."

SNOG3: "They are conservation exercises that have been done derived from certain federal government policies, that seek to find a denomination or a legal status to preserve areas that have a unique importance for certain species in particular, for birds, some other denominations for plant species or in unique ecological niches."

SPF2: "All the information obtained by the academic sector was backed up and validated with records from Conabio's Information System, as well as publications and the consensus of all researchers" (Figure 11). 


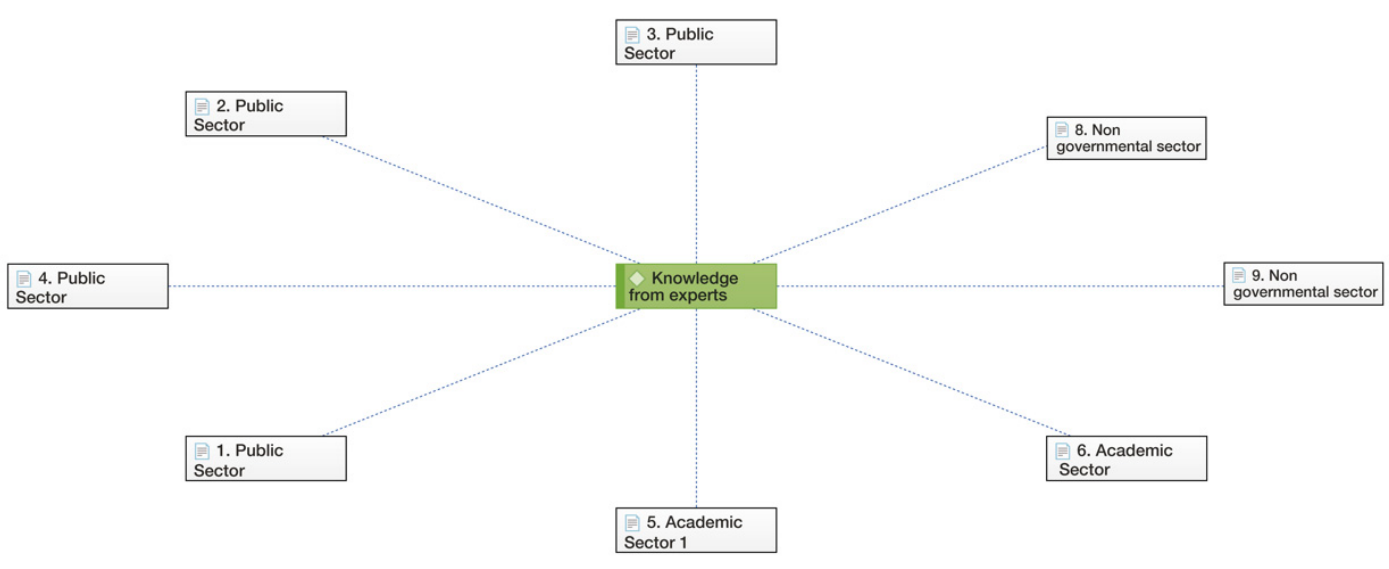

Figure 11. Identification of priority areas.

3.5.2. Question 2. What has been the Importance of the Priority Areas?

Interviewees from the public, academic and non-governmental sectors stated that the information on priority areas is very important, as it has been considered a baseline for planning and decision-making that have served as a reference over time (Figure 12).

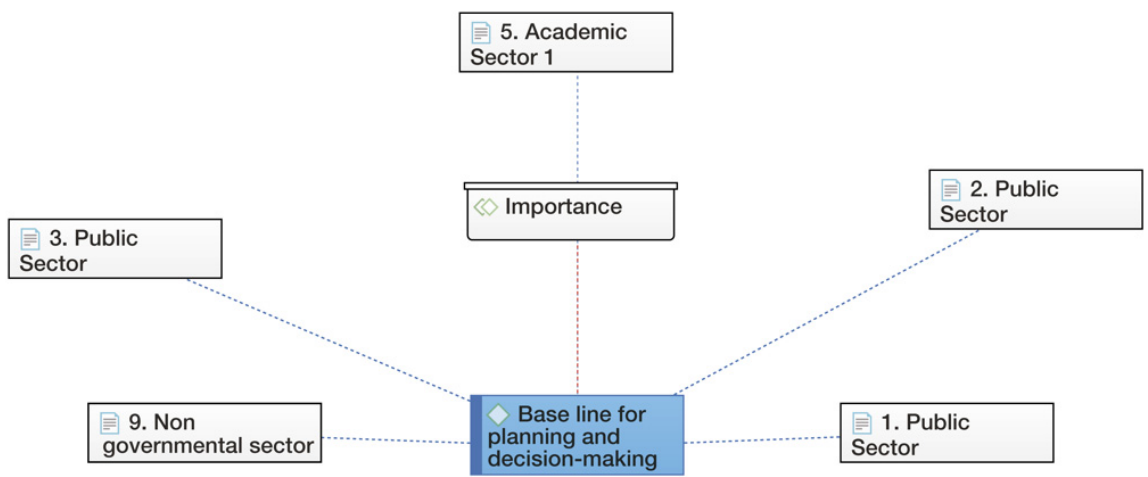

Figure 12. Importance of the priority areas.

Below are some fragments of the answers of the experts interviewed regarding the importance of the priority areas are as follows:

SP1F: "I believe that it has been a tool and that it has been used a lot, especially, the priority regions contributed a lot for planning in the states, to define natural areas, for environmental impact issues."

SA1: "The at the beginning they were intended to have a weight or a legal value, however, they are only taken as a reference in the studies, in the environmental impact statements in the management plans but nothing happens, that is, it does not have a legal value."

SONG3: "They are conservation exercises that have been done derived from certain federal government policies."

\subsubsection{Question 3. What Challenges do Their Management and Conservation Present?}

The answers to this question were grouped into 8 codes (legal basis-compliance with regulations, paper areas, lack of state and federal structure; planning; budget; lack of evaluation and monitoring; lack of commitment for effective management; managing the participation of different stakeholders and sectors; updating information and incorporating social aspects and lack of transversality in policies), which account for $81.42 \%$ of the quotes from interviewees from the public, non-governmental academic, private and PA community member sectors (Figure 13). 


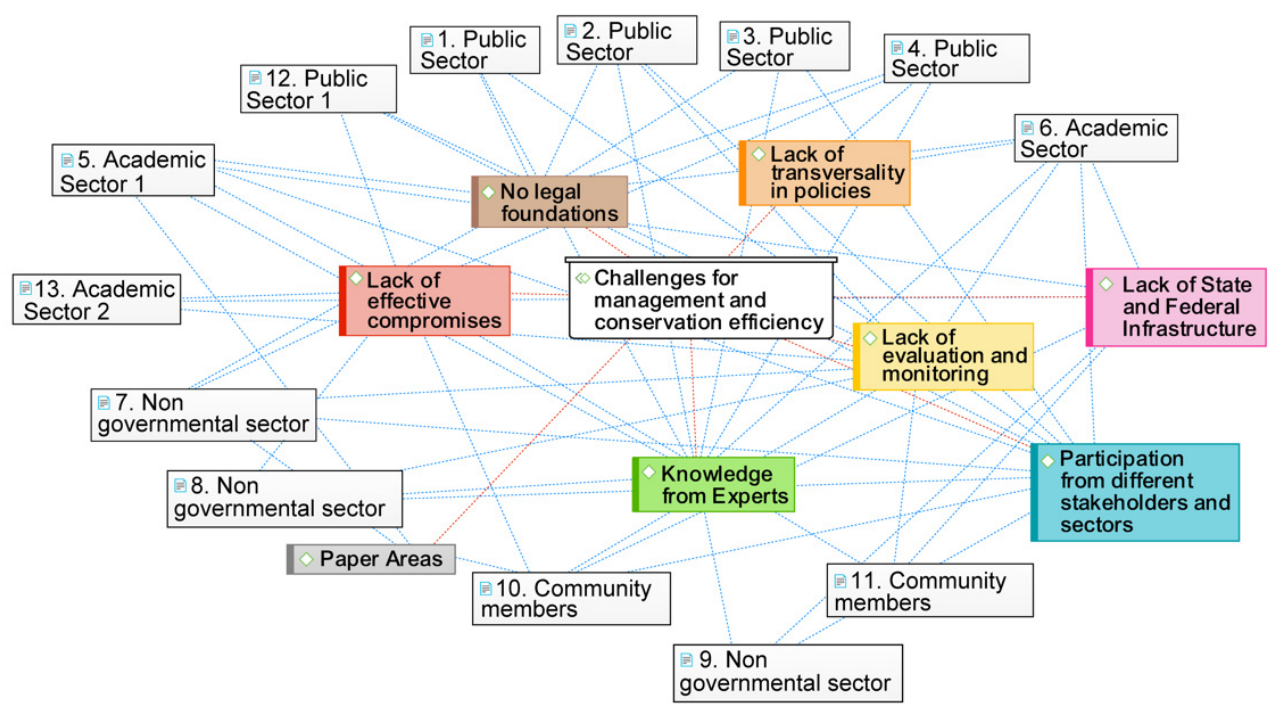

Figure 13. Challenges for management and conservation.

Below are some fragments of the answers of the experts' interviewed responses to the question of expressing the challenges for management and conservation. The fragments are classified into the categories that emerged from the global analysis of the responses.

Legal Basis-Compliance with Regulations

SP2: "There is no legal basis, but I believe it has not been a limitation for them to be considered important and not to be respected."

SA1: "Finally, since there is no management program and plan, there is no action by the federal government, the state government, the municipal government or anyone else, I believe that the only action was the delimitation."

SNG3: "The PAs are the ones that have a decree of creation, the other sites or regions are only interesting delimitations, without a law to support it, as not establishing monitoring and follow-up programs."

\section{Paper Areas}

SP3: "All this has remained in the structure of the texts, but it has not been possible to implement it because a very marked sectoral reality that does not allow for cross-cutting decision making and there is no coordination between different state secretariats."

SA2: "Those in charge of the PAs do not promote the dissemination of the regulations of each PA and therefore do not apply them."

SONG1: "We have natural protected areas, why do we want them if they are just there on paper? If we don't have a conservation strategy or a management plan? If there is no political will to solve the problems?"

SC1: "The policies made by the government and the management plans are very complete, but nothing is implemented in the community, and they are not taken into account, they are not applied."

\section{Lack of State and Federal Structure}

SPF2: "There is no law enforcement, monitoring and management programs are not properly implemented, there is no adequate vigilance, many of the personnel are not trained for the actions required to manage and conserve them, and there is a lack of information and dissemination of the importance of these areas."

SA1: "IF the natural protected areas have fulfilled their conservation purposes, but it has basically been because the communities have joined conservation efforts, they have appropriated the natural protected area this has been achieved through a lot of work that 
has been done in terms of environmental education, training for women, by institutions like the UAT and other universities that come and are immersed in the area, not so much by the government."

SONG1: "To do conservation you need a whole system of training organization, training and monitoring that unfortunately over the years has been increasingly diluted."

SP1: "We are not sure how PAs are managed, nor the sites they consider important for conservation, we do not know who to turn to if we see that something is being done incorrectly in any of the sites we visit."

SC1: "It is very important to provide security to all the people that visit us, suddenly the institutions that provide security are overwhelmed, it is very important must make alliances with the transporters, the environmental interpreters that exist in the communities."

Absence of Evaluation and Monitoring

SA1: "There is no control of what activities were going to be done each year according to the management plan."

SONG1: "Those in charge of these types of areas, do not propose in their annual operational programs, to have sufficient and justified resources to achieve compliance with the objectives and goals of conservation, restoration, training, operation, management, surveillance, signage, etc. ..."

SP2: "We have been visiting the sites for many years and we see how they are not taken care to the indifference of those responsible."

SC2: "The monitoring was done by us, this work was community surveillance or to ensure that environmental crimes were not committed or if they were committed, to raise the report so that sanctions could be taken for it, to take care of the mangrove, to prevent fishing with prohibited fishing gear, clandestine dumps, fires."

Lack of Commitment for Effective Management

SNG2: "Another reason why a really visible impact in the PAs is mainly since the people in charge of them, besides not knowing, are not $100 \%$ involved therefore, they do not enforce what is established in the creation decrees and their management programs and regulations."

SC1: "It is very important to see what the citizens are demanding, what the people who visit us are also demanding is water, solid waste that we have no management."

Manage the Participation of Different Stakeholders and Sectors

SPF1: "Well, it is a complex system, since it must be managed at different levels of government and with the communities, but the basis is there, now it is necessary to add perhaps on the part of the states, and of the educational institutions that are the ones who are present and know the communities and the changes, they must have documented and possess very valuable information."

SA1: "The work with the community authorities is very important."

SONG2: "Researchers do not send the results of their projects to the decision-makers of the different entities and levels related to biodiversity conservation."

SP1: "We can support the conservation of these sites so important for everyone."

SC1: "It is very important not to lose sight of the fact that society is not only made up of adults, but society is also made up of children and youth who also have something to contribute and are concerned about their environment."

Updating Information and Incorporating the Social Context

SPF1: "Subsequently, an analysis of gaps and omissions in conservation was carried out where, with updated information and at a finer scale, those sites important for their biodiversity were identified and the protected areas were superimposed to see if they covered the total of the polygon identified as a priority." 
SA1: "A new inventory of AICAS/IBAs at the national level because there are sites that were not included in the studies, and the social context should also be included."

SONG1: "I saw that the University is the natural stakeholder because it should carry out certification processes for people in the community that carry out conservation of natural resources, and they themselves should be leaders in updating the data."

Lack of Transversality

SPF1: "There is a lack of transversality in public policies and among the three levels of government: federal, state and municipal."

SPF3: "We should first work on the issue of sectorization and solve problems of mainstreaming and with that vision update and redefine the sites and their conservation."

SA2: "We should work on the connectivity of the areas, see them as a whole and analyze emerging issues such on in an integral and transversal way where the university and higher education institutions are of utmost importance."

\section{Discussion}

In response to the research question what are the challenges of an integrated management for effective biodiversity conservation in Tamaulipas?

The documental information and the interviews conducted allow us to assume that the main challenge is related to the fact that there are no conditions that support integral management for the effective conservation of biodiversity in Tamaulipas.

\subsection{Conservation, Regulation and Policies}

Regarding the regulations on the designation of the 39 areas that support the 70 designations considered as priority areas for conservation, there are 2 situations: the 13 natural protected areas in Tamaulipas have a creation decree or certificate issued by different levels of government, according to the LGEEPA [23]. In the case of the priority regions, 13 terrestrial, 5 hydrological and 5 marine, 13 AICAS/IBAs, 17 KBAS, 2MAB UNESCO and 2 Ramsar, there is no legal basis; they are areas that have been defined by national and international experts.

The elaboration of the management program is an obligation established in the LGEEPA and PA creation decrees, which state that from the publication of the creation decree, they have one year for elaboration and publication. It was found that not all of them comply with this regulation, and three situations were identified: the first is for one PA, El Cielo Biosphere Reserve, which has a management program, which was issued in a timely manner in 1986 . The second comprises five PAs whose management programs have been elaborated in a longer time than stipulated. The third comprises three PAs that lack a management program, including two federal: Rancho Nuevo Sanctuary (1986) and Sierra de Tamaulipas (2016); one state: Bernal de Horcasitas (1997); one municipal: Laguna de la Vega Escondida (2003). Of note is the Rancho Nuevo Sanctuary PA (1986), which is also a Ramsar site (1986) and is subject to protection due to the national importance it represents [61].

A requirement for PAs to be voluntarily designated for conservation is to present a management program in order to receive a certificate accrediting them as PAs.

The PA creation decrees establish the timeframe for updating and evaluating management programs. It was found that the established time periods are different: Laguna La Escondida and Parras de la Fuente: every five years; Altas Cumbres, with the periodicity established by the Government of the State of Tamaulipas, Reserva de la Biosfera El Cielo: at least every ten years; Laguna Madre and Delta del Rio Bravo: at least every five years. This situation, coupled with the lack of a state structure, makes conservation difficult, according to some of the interviewees, who highlighted that the management programs are complete, with many goals and actions, but they have not been updated, nor have they been evaluated for their effectiveness or put into practice. 
The PAs Colonia Parras de la Fuente, Laguna la Escondida and Laguna Madre and Delta Río Bravo were supposed to update their programs in 2020, but in the documents analyzed, no evidence was found that the NPA management programs have been updated; the presented data allow us to assume that some PAs in Tamaulipas exist only in the declaration document $[12,13]$.

A similar situation of non-compliance occurred in the case of the UNESCO MAB designations for El Cielo Biosphere Reserve (1986) and Laguna Madre and Río Bravo Delta (2006). The regulations of the UNESCO MAB program state that "periodic review is an important event in the life of a biosphere reserve. It requires a review every ten years of the functioning, zoning, and scale of the biosphere reserve, as well as the participation of the populations living in the site" [60]. In this sense, El Cielo Biosphere Reserve was evaluated in 2002 and 2013, while Laguna Madre and Delta del Río Bravo should have been evaluated in 2016, but they were not, which puts their designation at risk.

Why do 2 federal NPAs, the Rancho Nuevo Sanctuary with a decree of creation 35 years ago (1986) and the Sierra de Tamaulipas with a decree of creation five years ago (2016), not have management programs? On the other hand, regarding the NPAs of state and municipal origin (1997 and 2003), should it be established in the law that in the case of non-compliance with the regulations, regardless of the level of government, they should be cancelled? What happens as a result of the lack of compliance of the governments? This leads to the presumption that many of the NPAs are paper parks, which only exist in the declaration $[1,10,23]$.

The lack of compliance with the law and regulations that apply to them may be associated with the interviewees' statements that there is no commitment to conservation on the part of the three levels of government, nor knowledge of those responsible for their administration, together with the lack of a state structure for evaluation and monitoring, as well as the lack of the direct participation of members of other sectors, such as civil society, and the lack of transversality in the design of public policies.

\subsection{Status of Priority Areas for Diversity Conservation}

The absence of the evaluation of effective management in the NPAs is a constant at the global level. This is reflected in the non-compliance with the Aichi 11 target, established for 2020, which sought to "consolidate robust, effectively managed, representative and adequately connected systems of protected areas, as a strategy for sustaining over time these fundamental spaces for territorial conservation, human wellbeing and as natural solutions to climate change" [64] (p. 9).

The report issued by Mexico in 2020 on the Evaluation of the Effectiveness of Management or Management Effectiveness carried out states that the evaluation was executed on federal NPAs, which comply with three conditions: management program, assigned personnel and budget [53]; in the case of Tamaulipas, only one of the three federal NPAs complies with the established requirements. The Laguna Madre and Delta del Río Bravo obtained a highly effective index $[60,61,63]$.

Other elements are associated with the origins of the PNAs, which lead to the segmentation of the programs, and the lack of transversality or an integral approach, as highlighted by the interviewees, which is reflected in the overlap and the lack of integration of the PNAs and the priority regions, terrestrial marine regions, hydrological regions, AICAS/IBAs and KBAs, as well as the absence of long-term programs that develop integral or complete programs and landscapes or areas. This situation is not unique to Tamaulipas; as highlighted in [10]: "most protected areas in the world and their respective systems are governed by the state, which involves complex systems of entities, agencies, administrative levels and stakeholders that work with each other in collaboration, and sometimes in tension".

On the other hand, the results seem to confirm those of other studies regarding bias in the establishment of NPAs, since they are not always established in the most significant or important places. This may justify that out of 13 NPAs, only two are part of the National 
System of Natural Protected Areas (SINAP) due to the importance of biological diversity: Laguna Madre and Delta el Río Bravo, El Cielo Biosphere Reserve. [17,18]

In this sense, considering the PNAs as a basis for associating other national or international designations, it was found that in the Laguna Madre and Delta Río Bravo areas, there are six priority areas for conservation, five in El Cielo Biosphere Reserve and four in Sierra de Tamaulipas, which reflects the relevance of the zones. On the other hand, six PNAs have no association with other priority areas for biodiversity conservation.

In the case of governance, the 13 NPAs analyzed follow a traditional approach that has not managed to incorporate other important stakeholders for conservation. Experts interviewed from different sectors of the economy emphasize the importance of considering and involving civil society, the community, and local authorities with a long-term vision in an active manner through a different, adaptive governance [10]. This is consistent with the findings of other studies, indicating that the results obtained in some of the NPAs are not as expected, since it is difficult to harmonize biodiversity objectives with local values, needs and governance $[17,29]$, which can generate more inequalities, imbalances, and undesired results on biodiversity conservation. The research team also found that the lack of information monitoring and updating leads to a lack of knowledge on the status of PAs.

\subsection{Problems of the Priority Areas for Conservation}

The lack of evaluation and monitoring of PAs; priority terrestrial, hydrological and marine regions; AICAS/IBAs; and KBAS makes it impossible to determine the status of the areas, their biodiversity, and the social situation of the inhabitants, which in fact is not considered. Although it is considered that some areas, such as KBAs, do not necessarily require specific conservation actions through the figure of natural protected areas, it is recognized that their role in the conservation process is important [54].

The interviewees recognize that the importance of the conservation of priority areas is unquestionable, and that they should not remain in the decree or in the designation. However, the importance of the priority areas does not reflect the lack of compliance with the regulations since there is a lack of updated information on priority areas such as Laguna Madre and El Cielo Biosphere Reserve. The interviewees highlight that there is significant information on other sites that are not considered a priority and recognize that there are areas with information gaps and obsolete information.

The fragmentation of the information analyzed is perceived to be due to the lack of an interface between science and policy, the scarce dissemination of the results obtained by researchers and their distribution among different platforms, which does not facilitate a comprehensive analysis of a territory and also hinders its conservation.

The experts interviewed also highlighted the lack of a state structure, and the lack of commitment and knowledge of those responsible, which results in the lack of resources to carry out the minimum tasks described in the existing management programs, as well as the lack of participation of the authorities and local communities. This is also consistent with the findings in $[10,15,16]$ in PAs located in developing countries, which face situations that limit their work and the achievement of objectives, as they are immersed in a limited physical and administrative infrastructure or in a complex management hierarchy and inconsistent regulatory standards, issued by different governmental levels or departments, which hinder effective communication and information exchange $[10,15,16]$.

The interviewees highlight that the study on priority areas for conservation; terrestrial, marine, and hydrological regions; and AICAS/IBAs, and the analysis of gaps and omissions in 2007 , has been a very important contribution and a great advance. However, now it should be the states and local authorities that update the information and the status of the sites, and work in collaboration with multidisciplinary groups in long-term projects and in the process of permanent updating.

The challenges for management and conservation encountered, such as the lack of a state structure, lack of budget, lack of commitment of those responsible, long-term 
programs and paper areas, are in accordance with the description in $[6,14,15]$. The experts interviewed highlighted that the work carried out by state agencies depends on a momentary interest, not due to the fact that there is a strategic plan to guide the work, decision-making and conservation.

A demand of the interviewees is associated with the need to promote and expose the participation of different stakeholders and sectors, the network of volunteers, the important work carried out by communities and the diversity of stakeholders that remain invisible in the conservation process. This position coincides with that of $[12,13,17]$, who argue that PA managers should incorporate stakeholders who value, use, or enjoy the ES provided by a PA into the decision-making process $[13,17]$.

These results show the enormous complexity of achieving the conservation objective, which goes beyond a diversified and complementary set of other conservation instruments to ensure the permanence and functioning of ecosystems but requires adequate governance systems.

It is evident that governance is a pending issue in the priority areas for conservation in Tamaulipas, which is evident in documents and interviews with experts, and is reflected in information gaps and the lack of a state structure [1,22]. Good governance is also fundamental for effective and equitable conservation; its analysis allows the identification of essential aspects, such as ensuring legitimacy, voice, transparency and accountability, and the ability to respond adaptively to meet conservation objectives $[10,12]$.

\section{Conclusions}

After analyzing the current situation of conservation in Tamaulipas through existing literature, documents, and interviews with experts, it can be concluded that conservation in Tamaulipas and its objectives have not been achieved accordingly.

The different instances have not been able to move towards an effective governance, which makes impossible the construction of productive and coherent interactions between people, sectors, and stakeholders' decision-making levels.

As a result, different conservation schemes converge and overlap in the same area, but do not establish an interconnection in the analysis and conservation efforts, and demonstrate fragmentation, legal, structural, and administrative gaps. This generates a limited understanding of the effects that fragmentation has on conservation, and the absence of research and actions to reverse it.

Information gaps have limited a deeper understanding of biodiversity. The impact of the threats in most of the priority areas is unknown; therefore, it is necessary to strategically plan and continue with research efforts, especially in areas identified as having the highest value and the least studied in order to establish the interfaces between science and public policies.

This research study demonstrated that policies had not been previously addressed in the conservation areas in the state of Tamaulipas. Our findings aligned with similar situations within other priority areas for conservation in other developing countries, which are immersed in a bureaucratic and complex system.

Effectiveness in the management of priority areas for conservation entails the development of capacities to meet the demands of funders, officials, and society in general, the foundations of good governance based on shared values and objectives. In this context, countries such as China, Iceland and Bangladesh are exploring new governance schemes such as co-management or the participatory approach from which they assume that the basic objective of protected areas is not only to preserve natural ecosystems and biodiversity, but also to ensure the economic development of the surrounding areas, or the integrated management of a territory. Our work proposes a systematic mapping of the state of knowledge of key areas for biodiversity conservation would make it possible to identify long-term priorities and actions and guide the work of researchers, practitioners, decision-makers, and the community in favor of effective biodiversity conservation. Therefore, the work subsequent to this research is coordinated from the Autonomous University 
of Tamaulipas (Universidad Autónoma de Tamaulipas in Spanish) and is sustained in the existence of expert knowledge in the local higher education institutions and the alliances built by researchers for more than 30 years with the community as well as with national and international organizations.

The construction of a state system for conservation and digital transformation has been initiated through a long-term trans-disciplinary project in which the public, academic, private, and non-governmental sectors interact simultaneously, which deals with the importance of citizen science, and, sub-sequent, the leadership and commitment to update the information on priority areas. Moreover, identifying new priority areas, evaluating, monitoring the rescue of traditional knowledge and the integration of a state conservation system that is available in real time to the public could enable the empowerment of citizens and the enrichment of citizen science.

Author Contributions: Conceptualization, F.C.C.-R. and R.V.R.-H.; methodology, F.C.C.-R. and R.V.R.-H.; software, R.V.R.-H. and R.d.l.G.C.; validation, E.A.-S. and F.C.C.-R.; formal analysis, F.C.C.-R. and R.V.R.-H.; investigation, F.C.C.-R., R.V.R.-H. and E.A.-S.; resources, E.A.-S. and R.d.l.G.C.; F.C.C.-R.; writing—original draft preparation, F.C.C.-R., R.V.R.-H. and R.d.l.G.C.; writing-F.C.C.-R., R.d.l.G.C. and R.V.R.-H.; visualization, F.C.C.-R. and E.A.-S.; supervision, F.C.C.-R., E.A.-S. and R.d.l.G.C.; project administration, E.A.-S. and R.V.R.-H. All authors have read and agreed to the published version of the manuscript.

Funding: This research received no external funding.

Institutional Review Board Statement: This project has been evaluated by a committee of expert investigators and has been deemed to present no risk to the interviewees. Therefore, it has not been reviewed by any of the University's Human Ethics Committees. The investigator(s) named in this document are responsible for the ethical conduct of this research.

Informed Consent Statement: Informed consent was obtained from all subjects involved in the study.

Data Availability Statement: The data presented in this study are available on request from the corresponding author.

Acknowledgments: We are grateful for the support provided by the interview participants who made this research possible, and to the Autonomous University of Tamaulipas for the financial support for the publication of the article. Additionally, authors would like to thank Birdlife international (2020) World Database of Key Biodiversity Areas for the KBA dataset of Mexico. We are also grateful to Ana Mónica de Jesúh Garcia Garcia for the preparation of maps.

Conflicts of Interest: The authors declare no conflict of interest.

\section{References}

1. Borrini-Feyerabend, G.; Dudley, N.; Jaeger, T.; Lassen, B.; Pathak, N.; Philips, A.; Sandwith, T.; Protegidas, Á. Gobernanza de Áreas Protegidas: De la Comprensión a la Acción; UICN: Gland, Switzerland, 2014.

2. Palomo, I.; Martín-López, B.; Zorrilla-Miras, P.; del Amo, D.; Montes, C. Deliberative Mapping of Ecosystem Services within and around Doñana National Park (SW Spain) in Relation to Land Use Change. Reg. Environ. Chang. 2013, 14, 237-251. [CrossRef]

3. Crawhall, N. Influencias Sociales y Económicas Que Moldean las Áreas Protegidas; Worboys, G.L., Lockwood, M., Kothari, S., Feary, E., Pulsford, I., Eds.; Gobernanza y Gestión de Areas Protegidas. Editorial Universidad El Bosque y ANU Press: Bogotá, Colombia, 2019; pp. 119-148.

4. He, M.; Cliquet, A. Challenges for Protected Areas Management in China. Sustainability 2020, 12, 5879. [CrossRef]

5. Lopoukhine, N.; Crawhall, N.; Dudley, N.; Figgis, P.; Karibuhoye, C.; Laffoley, D.; Londoño, J.; MacKinnon, K.; Sandwith, T. Protected Areas: Providing Natural Solutions to 21st Century Challenges. Sapiens 2012, 5, 116-131.

6. Woodley, S.; Locke, H.; Laffoley, D.; MacKinnon, K.; Sandwith, T.; Smart, J. A Review of Evidence for Area-based Conservation Targets for the Post-2020 Global Biodiversity Framework. PARKS 2019, 25, 31-46. [CrossRef]

7. Mackinnon, K.; Mrema, E.M.; Richardson, K.; Cooper, D.; Gidda, S. Editorial Essay: Protected and Conserved Areas: Contributing to More Ambitious Conservation Outcomes Post-2020. PARKS 2021, 27, 7-12. [CrossRef]

8. Mulongoy, K.J.; Babu Gidda, S. The Value of Nature: Ecological, Economic, Cultural and Social Benefits of Protected Areas; Secretariat of the Convention on Biological Diversity: Montreal, QC, Canada, 2008.

9. Loos, J. Reconciling Conservation and Development in Protected Areas of the Global South. Basic Appl. Ecol. 2021, 54, 108-118. [CrossRef] 
10. Borrini-Feyerabend, G.; Hill, R. Gobernanza Para La Conservación de La Naturaleza; ANU Press: Canberra, Australia, 2019. [CrossRef]

11. Xu, W.; Pimm, S.; Du, A.; Su, Y.; Fan, X.; An, L.; Liu, J.; Ouyang, Z. Transforming Protected Area Management in China. Trends Ecol. Evol. 2019, 34, 762-766. [CrossRef]

12. Geldmann, J.; Coad, L.; Barnes, M.; Craigie, I.; Hockings, M.; Knights, K.; Leverington, F.; Cuadros, I.; Zamora, C.; Woodley, S.; et al. Changes in Protected Area Management Effectiveness over Time: A Global Analysis. Biol. Conserv. 2015, 191, 692-699. [CrossRef]

13. Coad, L.; Watson, J.; Geldmann, J.; Burgess, N.; Leverington, F.; Hockings, M.; Knights, K.; di Marco, M. Widespread Shortfalls in Protected Area Resourcing Undermine Efforts to Conserve Biodiversity. Front. Ecol. Environ. 2019, 17, 259-264. [CrossRef]

14. Visconti, P.; Butchart, S.; Brooks, T.; Langhammer, P.; Marnewick, D.; Vergara, S.; Yanosky, A.; Watson, J. Protected Area Targets Post-2020. Science 2019, 364, eaav6886. [CrossRef]

15. Mukul, S.A.; Sohel, M.S.I.; Herbohn, J.; Inostroza, L.; König, H. Integrating Ecosystem Services Supply Potential from Future Land-Use Scenarios in Protected Area Management: A Bangladesh Case Study. Ecosyst. Serv. 2017, 26, 355-364. [CrossRef]

16. Cao, M.; Peng, L.; Liu, S. Analysis of the Network of Protected Areas in China Based on a Geographic Perspective: Current Status, Issues and Integration. Sustainability 2015, 7, 15617-15631. [CrossRef]

17. Hockings, M.; Dudley, N.; Ellio, W.; Ferreira, M.; Mackinnon, K.; Pasha, M.; Phillips, A.; Stolton, S.; Woodley, S.; Appleton, M.; et al. COVID-19 and Protected and Conserved Areas. PARKS 2020, 26, 7-24. [CrossRef]

18. Margules, C.; Pressey, R. Systematic Conservation Planning. Nature 2000, 405, 243-253. [CrossRef]

19. Maxwell, S.L.; Cazalis, V.; Dudley, N.; Hoffmann, M.; Rodrigues, A.S.L.; Stolton, S.; Visconti, P.; Woodley, S.; Kingston, N.; Lewis, E.; et al. Author Correction: Area-Based Conservation in the Twenty-First Century. Nature 2020, 588, E14. [CrossRef]

20. Dearden, P.; Bennett, M.; Johnston, J. Trends in Global Protected Area Governance, 1992-2002. Environ. Manag. 2005, 36, 89-100. [CrossRef] [PubMed]

21. Lockwood, M.; Worboys, G.; Kothari, A. Managing Protected Areas: A Global Guide; Earthscan: London, UK, 2006.

22. Spoelder, P.; Lockwood, M.; Cowell, S.; Gregerson, P.; Henchman, A. Planeación. In Gobernanza y Gestión de Áreas Protegidas; ANU Press: Canberra, Australia, 2019.

23. Worboys, G. Concept, Purpose and Challenges; ANU Press: Canberra, Australia, 2015. [CrossRef]

24. Figueroa, F.; Sánchez-Cordero, V. Effectiveness of Natural Protected Areas to Prevent Land Use and Land Cover Change in Mexico. Biodivers. Conserv. 2008, 17, 3223-3240. [CrossRef]

25. Ostrom, E. A General Framework for Analyzing Sustainability of Social-Ecological Systems. Science 2009, 325, 419-422. [CrossRef] [PubMed]

26. Díaz, S.; Settele, J.; Brondízio, E.S.; Ngo, H.T.; Agard, J.; Arneth, A.; Balvanera, P.; Brauman, K.A.; Butchart, S.H.M.; Chan, K.M.A.; et al. Pervasive Human-Driven Decline of Life on Earth Points to the Need for Transformative Change. Science 2019, 366, eaax3100. [CrossRef]

27. Toledo, V.M. El Metabolismo Social: Una Nueva Teoría Socioecológica. Relac. Estud. Hist. Soc. 2013, 34, 41-71. [CrossRef]

28. Stevance, A.-S.; Bridgewater, P.; Louafi, S.; King, N.; Beard, T.; van Jaarsveld, A.; Ofir, Z.; Kohsaka, R.; Jenderedijan, K.; Rosales, M.; et al. The 2019 Review of IPBES and Future Priorities: Reaching beyond Assessment to Enhance Policy Impact. Ecosyst. People 2019, 16, 70-77. [CrossRef]

29. Oldekop, J.; Holmes, G.; Harris, W.; Evans, K. A Global Assessment of the Social and Conservation Outcomes of Protected Areas. Conserv. Biol. 2015, 30, 133-141. [CrossRef]

30. Rees, S.E.; Pittman, S.J.; Foster, N.; Langmead, O.; Griffiths, C.; Fletcher, S.; Johnson, D.E.; Attrill, M. Bridging the Divide: Social-Ecological Coherence in Marine Protected Area Network Design. Aquat. Conserv. Mar. Freshw. Ecosyst. 2018, 28, 754-763. [CrossRef]

31. He, M.; Cliquet, A. Sustainable Development through a Rights-Based Approach to Conserve Protected Areas in China. China-EU Law J. 2014, 3, 143-163. [CrossRef]

32. Xu, W.; Xiao, Y.; Zhang, J.; Yang, W.; Zhang, L.; Hull, V.; Wang, Z.; Zheng, H.; Liu, J.; Polasky, S.; et al. Strengthening Protected Areas for Biodiversity and Ecosystem Services in China. Proc. Natl. Acad. Sci. USA 2017, 114, 1601-1606. [CrossRef] [PubMed]

33. Petursson, J.G.; Kristofersson, D.M. Co-Management of Protected Areas: A Governance System Analysis of Vatnajökull National Park, Iceland. Land 2021, 10, 681. [CrossRef]

34. Arriaga, L.; Espinoza, J.M.; Aguilar, C.; Martínez, E.; Gómez, L.; Loa, E. Regiones Terrestres Prioritarias de México; Comisión Nacional Para El Conocimiento y Uso de la Biodiversidad: Ciudad de Mexico, Mexico, 2000.

35. Benítez, H.; Arizmendi, C.; Márquez, L. Base de Datos de Las AICAS. CIPAMEX, CONABIO, FMCN y CCA. México. 1999. Available online: http:/ / www.conabio.gob.mx (accessed on 22 March 2021).

36. Bezaury-Creel, J.; Gutiérrez-Carbonell, D.; Remolina, J.F. Áreas Naturales Protegidas y Desarrollo Social En México. Cap. Nat. México 2009, 2, 385-431.

37. Equipo Editorial. Declaración de Helsinki de La Asociación Médica Mundial. Arbor. Cienc. Pensam. Cult. 2008, $184,730$.

38. ATLAS.ti. Available online: https: / / atlasti.com/es / (accessed on 12 September 2021).

39. Diario Oficial de la Federación. Ley General Del Equilibrio Ecológico y La Protección al Ambiente. 1988. Available online: http: //www.paot.mx/centro/leyes/federales/pdf/2015/LEY_GENERAL_EQUILIBRIO_ECOLOGICO_09_01_2015.pdf (accessed on 2 May 2021). 
40. Periódico Oficial el Gobierno del Estado de Tamaulipas. Decreto Expedido por el Ejecutivo del Estado por Medio del Cual, por Causa de Utilidad Pública, Se Declara Área Ecológica Protegida, Clasificada como Reserva de la Biosfera El Cielo; Secretaría General del Gobierno del Estado de Tamaulipas (SGG): Ciudad Victoria, Mexico, 1985.

41. Diario Oficial de la Federación. DECRETO Por el Que se Determinan Como Zonas de Reserva y Sitios de Refugio para la Protección, Conservación, Repoblación, Desarrollo y Control, de las Diversas Especies de Tortuga Marina, Los Lugares En Que Anida y Desova Dicha Especie; Diario Oficial de la Federación: Ciudad de México, México, 1986.

42. Periódico Oficial el Gobierno del Estado de Tamaulipas. Acuerdo Gubernamental Mediante el Cual se Declara Área Protegida Ecológica La Zona Denominada "Colonia Parras de La Fuente", del Municipio de Abasolo Tamaulipas; Periódico Oficial el Gobierno del Estado de Tamaulipas: Ciudad Victoria, Mexico, 1992.

43. Periódico Oficial el Gobierno del Estado de Tamaulipas. Acuerdo Gubernamental Mediante el Cual se Declara Área Natural Protegida, Clasificada Como Parque Urbano El Área Denominado "Laguna La Escondida", del Municipio de Reynosa, Tamaulipas; Periódico Oficial el Gobierno del Estado de Tamaulipas: Ciudad Victoria, Mexico, 1997.

44. Periódico Oficial el Gobierno del Estado de Tamaulipas. Acuerdo Gubernamental Mediante el Cual se Declara Área Natural Protegida, Clasificada Como Monumento Natural, a la Zona Denominada Como "Bernal de Horcasitas", Que Se Localiza en el Municipio de González, Tamaulipas; Periódico Oficial el Gobierno del Estado de Tamaulipas: Ciudad Victoria, Mexico, 1997.

45. Periódico Oficial el Gobierno del Estado de Tamaulipas. Acuerdo Gubernamental Mediante el Cual se Declara Área Natural Protegida, Clasificada Como Zona Especial Sujeta a Conservación Ecológica Con el Nombre de "Área Natural Protegida Altas Cumbres", del Municipio de Ciudad Victoria, Tamaulipas; Periódico Oficial el Gobierno del Estado de Tamaulipas: Ciudad Victoria, Mexico, 1997.

46. Periódico Oficial el Gobierno del Estado de Tamaulipas. Acuerdo Municipal, Mediante el Cual se Declara Área Natural Protegida, Clasificada Como Zona Especial Sujeta a Conservación Ecológica el Área Denominada "LA VEGA ESCONDIDA", Ubicada En El Municipio de Tampico, Tamaulipas; Periódico Oficial el Gobierno del Estado de Tamaulipas: Ciudad Victoria, Mexico, 1997.

47. Diario Oficial de la Federación. DECRETO Por el Que Se Declara Área Natural Protegida, con el Carácter de Área de Protección de Flora y Fauna, la Región Conocida como Laguna Madre y Delta del Río Bravo, Ubicada en los Municipios de Matamoros, San Fernando y Soto La Marina, en el Estado de Tamaulipas. Available online: http:/ / www.dof.gob.mx/nota_detalle.php?codigo=49 $19407 \&$ fecha $=14 / 04 / 2005$ (accessed on 11 September 2021).

48. CONANP. Áreas Destinadas Voluntariamente a La Conservación: Número de Certificado: CONANP-42/2006: Rancho San Pedro: Antiguo Morelos, Tamaulipas; CONANP: Ciudad de México, Mexico, 2006.

49. CONANP. Áreas Destinadas Voluntariamente a La Conservación: Número de Certificado: CONANP-249/2011: Reserva Bio Ventura: Aldama, Tamaulipas; CONANP: Ciudad de México, Mexico, 2011.

50. CONANP. Áreas Destinadas Voluntariamente a La Conservación. Número de Certificado: CONANP-447/2019: Rancho Regalo de Dios: Ocampo, Tamaulipas; CONANP: Ciudad de México, Mexico, 2019.

51. Periódico Oficial el Gobierno del Estado de Tamaulipas. DECRETO Gubernamental por el Que se Declara Como Área Natural Protegida con la Categoría de Parque Estatal, Denominado "el Refugio", Localizado en el Municipio de Victoria, Tamaulipas; Periódico Oficial el Gobierno del Estado de Tamaulipas: Ciudad Victoria, Mexico, 2015.

52. Diario Oficial de la Federación. DECRETO por el Que se Declara Área Natural Protegida, con el Carácter de Reserva de la Biosfera, la Región Conocida como Sierra de Tamaulipas, Localizada en los Municipios de Aldama, Casas, González, Llera y Soto La Marina, en el Estado de Tamaulipas. Available online: https: / /www.dof.gob.mx/nota_detalle.php?codigo=5464453\&fecha=07/12/2016 (accessed on 11 September 2021).

53. CONANP. Primer Informe Nacional de Evaluación de La Efectividad del Manejo de las Áreas Naturales Protegidas de México Abril 2020 Ciudad de México; CONANP: Ciudad de México, Mexico, 2020.

54. UNEP-WCMC (2021). Protected Area Profile for Laguna Madre from the World Database of Protected Areas, December 2021. Available online: www.protectedplanet.net (accessed on 8 September 2021).

55. BirdLife International. World Database of Key Biodiversity Areas. Developed by the KBA Partnership: BirdLife International, International Union for the Conservation of Nature, American Bird Conservancy, Amphibian Survival Alliance, Conservation International, Critical Ecosystem Partnership Fund, Global Environment Facility, Global Wildlife Conservation, NatureServe, Rainforest Trust, Royal Society for the Protection of Birds, Wildlife Conservation Society and World Wildlife Fund. September 2020. Available online: http: //www.keybiodiversityareas.org/site/requestgis (accessed on 11 September 2021).

56. Key Biodivesity Areas. Key Biodivesity Areas Data. Available online: http://www.keybiodiversityareas.org/kba-data (accessed on 11 September 2021).

57. Boucher, J.; Brooks, M.; Cuttelod, A.; Dudley, N.; Langhammer, P.F. Applications of Key Biodiversity Areas: End-User Consultations; IUCN: Gland, Switzerland, 2014.

58. Arriaga, L.; Vázquez-Dominguez, E.; González-Cano, J.; Jiménez-Rosenberg, R.; Muñoz-López, E.; Aguilar-Sierra, V. Regiones Marinas Prioritarias de México; Comisión Nacional para el Conocimiento y uso de la Biodiversidad: Ciudad de Mexico, Mexico, 1998.

59. Arriaga Cabrera, L.; Aguilar Sierra, V. Aguas Continentales y Diversidad Biológica de México; Comisión Nacional para el Conocimiento y Uso de la Biodiversidad: Ciudad de Mexico, Mexico, 2000.

60. MAB-UNESCO. Biosphere Reserves in Latin America and the Caribbean. Available online: https://en.unesco.org/biosphere/lac (accessed on 11 September 2021).

61. RAMSAR. Mexico I Ramsar. Available online: https://www.ramsar.org/wetland/mexico (accessed on 11 September 2021). 
62. Conabio-Conanp-TNC-Pronatura-FCF, UANL. Análisis de Vacios y Omisiones en Conservación de la Biodiversidad Terrestre de México: Espacios y Especies; Universidad Autónoma de Nuevo León: México City, Mexico, 2007.

63. CONABIO; CONANP; TNC; PRONATURA. Análisis de Vacios y Omisiones en Conservación de la Biodiversidad Marina de México: Océanos, Costas e Islas; Pronatura, A.C., México, D.F., Eds.; The Nature Conservancy-Programa México: México City, Mexico, 2007; p. 7.

64. RedParques, P.I.; México, P. Progreso de Cumplimiento de la Meta 11 de Aichi en los Países de la Redparques: Resultados y Perspectivas al 2020; CDB; Proyecto IAPA; Unión Europea; WWF; FAO; UICN; ONU Medio Ambiente: Bogotá, Colombia, 2018 ; Volume 46. Available online: https://www.portalces.org/sites/default/files/documentos/9._informe_meta_11_aichi_latinoamerica_low_ .pdf (accessed on 22 March 2021). 